九州大学学術情報リポジトリ

Kyushu University Institutional Repository

\title{
X-Ray Studies Of Wood
}

Nagasawa, Takeo

Institute of Agronomy, Kyushu Imperial University

https://doi.org/10.5109/22584

出版情報 : 九州大学大学院農学研究院紀要. 5(5)，pp.237-269，1937-03. Kyushu Imperial University バージョン：

権利関係 : 
Journal of the Department of Agriculture, Kyûshâ Imperial University, Vol. 5, No. 5 . May 1, 1937

\title{
X-RAY STUDIES OF WOOD
}

\author{
Takeo Nấẫ
}

I. Introduction.

\section{CONTENTS}

II. Direct X-ray results on the crystal structure of wood.

III. Explanation of the various patterns of diffraction figures of the wood fibres.

IV. Diffraction figures and the strength of wood.

$\mathrm{V}$. On a new method of measuring the internal strength in fixed wooden materials of large size.

VI. X-ray absorption of wood.

VII. Summary.

Bibliography.

\section{INTRODUCTION}

In 1862 a Swiss botanist NÄGELI assumed that the materials which compose vegetable fibre, starch, silk etc., are constituted from ultra microscopic crystaline molecular complexes called "micelle".

This hypothesis served to explain weli some features of the nature of the construction of plants. Of the X-ray study of vegetable fibre, Prof. S. Nishikawa is the pioneer, and in 1913 he proved scientifically that the plant fibre is composed of microcrystals.

Later H. Ambronn showed that the plant fibre has the nature of double reflection. Since then many scholars, such as SCHERrer, Herzog, Polanyi, Jancke, Mark and Meyer etc., have engaged in the X-ray study of fibre. MARK concluded that the micelle crystals of the plant fibre belong to the monoclinic system.

Almost all of the researchers mentioned above confined their investigations mainly to substances whose chemical constructions were rather genuine.

In the present paper, the author presents the results of studies by the X-ray method in the construction nature of wood, the aggregates of many chemical compounds, as a whole. 


\section{DIRECT X-RAY RESULTS ON THE CRYSTAL STRUCTURE OF WOOD}

Over two hundred X-ray photographs of wood have been taken, using copper $K_{x}$ radiation and iron $K_{\star}$ radiation. (The former was filtered off the $K_{r}$ line by nickel foil about $1 / 100 \mathrm{~mm}$. thick. The


peroxide attached to cellophane). The slit was a circular aperture whose diameter is $0.1 \mathrm{~mm}$. The scattered rays from which were screened off in the usual manner by a secondary slit. With this arrangement, SHEARER tube, and an unrectified transformer, photographs of small piece of wood of $1.0-0.5 \mathrm{~mm}$. thick may be obtained in about 30 hours exposure by a current of $5-8$ milli amperes and $40-50 \mathrm{KV}$. in tension.

An interpretation of the spacings of the DEBYE-SCHERRER rings, the indexing of planes corresponding to the intensity maxima of the fibre pattern, a straight forward measurement of the identity period along the fibre axis from the position of the layer line hyperbolas, and a careful analysis of intensities, have led MARK and Meyer to an analysis of crystalline cellulose which is now generally considered to be correct. There may be some differences still as to the complete model of cellulose constructed upon the experimental data.

For wood, the author confirmed these data independently. First of all, therefore, the spacial unit, or unit crystal cell which has the fundamental properties of cellulose was selected by X-ray. Of these points, the results attained were as follows.

From the data obtained from the sample "Sugi" (Cryptomeria japonica, DON), assuming the crystal system to be monoclinic, the following quadratic equation was obtained;

$$
-4 \sin ^{2} \theta=0.0147 h^{2}+0.0095 k^{2}+0.0165 l^{2}+0.0033 h l
$$

where $\lambda$ is the wave length of the X-ray employed, expressed by A. U., and $h, k, l$ are the indices of the atomic planes, and $H$ is the glancing angle of X-ray, by taking the dimension of an unit cell of wood fibre as

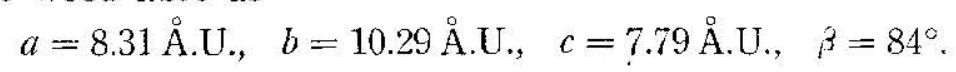

The values of $-\frac{4 \sin ^{2} \theta}{h^{2}}-$ calculated and observed are tabulated in Table $\mathrm{I}$. 
Table I

\begin{tabular}{|c|c|c|c|c|}
\hline \multirow{2}{*}{ Spots } & \multirow{2}{*}{ Indices } & \multicolumn{2}{|c|}{$\frac{4}{x^{2}} \sin ^{2} \theta$} & \multirow{2}{*}{ Intensities } \\
\hline & & Calculated & Observed & \\
\hline & 100 & 0.0147 & 0.0150 & w. \\
\hline$A_{1}$ & 001 & 0.0166 & 0.0170 & w. \\
\hline $\mathrm{A}_{2}$ & 101 & 0.0280 & 0.0286 & st. \\
\hline $\mathrm{A}_{3}$ & $10 \overline{1}$ & 0.0346 & 0.0348 & st. \\
\hline $\mathrm{A}_{1}$ & 002 & 0.0664 & 0.0668 & v. st. \\
\hline$A_{5}$ & 004 & 0.2656 & 0.2670 & $\mathrm{~m}$. \\
\hline $\mathrm{I}_{2}$ & 310 & 0.1417 & 0.1420 & $\mathrm{~m}$ \\
\hline $\mathrm{I}_{2}$ & 213 & 0.1978 & 0.1950 & w. \\
\hline $\mathrm{II}_{1}$ & 021 & 0.0542 & 0.0544 & st. \\
\hline $\mathrm{HI}_{2}$ & 221 & 0.1064 & 0.1080 & st. \\
\hline $\mathrm{II}_{j}$ & $22 \overline{1}$ & 0.1196 & 0.1230 & st. \\
\hline $\mathrm{III}_{1}$ & 031 & 0.1012 & 0.1010 & $\mathrm{~m}$. \\
\hline $\mathrm{III}_{2}$ & 131 & 0.1126 & 0.1180 & $\mathrm{~m}$. \\
\hline $\mathrm{III}_{\dot{a}}$ & 230 & 0.1434 & 0.1480 & m. st. \\
\hline $\mathrm{III}_{4}$ & $13 \overline{2}$ & 0.1723 & 0.1740 & w. \\
\hline $\mathrm{III}_{\mathrm{i}}$ & $23 \overline{2}$ & 0.2230 & 0.2290 & w. \\
\hline $\mathrm{HII}_{\mathrm{F}_{\mathrm{j}}}$ & $33 \overline{1}$ & 0.2434 & 0.2510 & w. \\
\hline$I V_{1}$ & 040 & 0.1504 & 0.1530 & m. st. \\
\hline $\mathrm{IV}_{2}$ & 141 & 0.1784 & 0.1750 & w. \\
\hline $\mathrm{IV}_{3}$ & 240 & 0.2092 & 0.2100 & st. \\
\hline $\mathrm{IV}_{4}$ & 143 & 0.3046 & 0.2970 & w. \\
\hline $\mathrm{V}_{1}$ & 051 & 0.2516 & 0.2580 & w. \\
\hline$V_{2}$ & 251 & 0.3038 & 0.3200 & w. \\
\hline
\end{tabular}


The observed values given in the fourth column are those obtained by the author.

By assuming the form and the size of the unit cell of wood cellulose to be as stated above, the author calculated the number of the $\left(\mathrm{C}_{6} \mathrm{H}_{10} \mathrm{O}_{5}\right)$-groups contained in an unit cell. The volume of an unit cell is equal to

$$
\begin{aligned}
\mathrm{V}_{\mathrm{c}} & =a . b . c . \sin 84^{\circ} \\
& =8.31 \times 10.29 \times 7.79 \times 10^{-24} \times 0.9945 \mathrm{cc} . \\
& =662.45 \times 10^{-24} \mathrm{cc} .
\end{aligned}
$$

Again assuming the net density of wood cellulose to be equal to that of the native cellulose, which is 1.614 , the mass of an unit cell becomes

$$
\begin{aligned}
\mathrm{M}_{\mathrm{c}} & =\rho \mathrm{V} \\
& =1.614 \times 662.45 \times 10^{-22} \mathrm{gr} . \\
& =10.69 \times 10^{-22} \mathrm{gr} .
\end{aligned}
$$

As the mass of a $\left(\mathrm{C}_{6} \mathrm{H}_{10} \mathrm{O}_{5}\right)$-group is equal to

$$
\begin{aligned}
\mathrm{M}_{\mathrm{m}} & =\frac{162}{6.06 \times 10^{-23}} \mathrm{gr} . \\
& =2.67 \times 10^{-22} \mathrm{gr} .
\end{aligned}
$$

the number of the $\left(\mathrm{C}_{6} \mathrm{H}_{10} \mathrm{O}_{5}\right)$-groups contained in an unit cell becomes

$$
\begin{aligned}
\mathrm{N} & =-\frac{\mathrm{M}_{c}}{\mathrm{M}_{2: 2}} \\
& =\frac{10.69 \times 10^{-22}}{2.67 \times 20^{22}} \\
& =4.004 .
\end{aligned}
$$

This number is approximately equal to four.

\section{EXPLANATION OF 'IHE VARIOUS PATTERNS OF DIFFRACTION FIGURES OF THE WOOD FIBRES}

It has been indirectly verified that wood fibre micelles are laid down spirally in the cell wall. FREUDENBERG has suggested that the wood micelles are arranged in only one common direction in the fibre. 
PIENKowsKIE estimated the degree of orientation of micelles from the extent of ares in the equator along the DeByE rings. He insisted that the arcs are caused by a broad deviation of the micelles from the axis of the wood cell. But he said nothing about the micelles being oriented spirally in the cell wall. CLARK considered the patterns to be such as pl. 6, fig. 2 are produced only by natural (i.e. leaning side of trunks and under side of boughs) or artificial compression. But in our experiment, even in the uncompressed state, this type has been scen.

Of the more than two hundred LAUE photographs which were taken, the typical forms are reproduced and shown at the end of this report.

The writer's opinion upon the causes of the diffraction patterns is as follows:

When the X-ray beam passes through parallel to the long axis of the wood fibres, there appear only DEBYE rings, which shows that there is no preferred orientation of the cellulose micelles. As to the diffraction patterns of the tangential and radial cross sections, the orientations of the micelles are generally perfect, and the degrees of the orientation of the both sections are nearly similar, so, in the present investigation only tangential sections are used, as representative of such orientation.



Text-fig. 1.

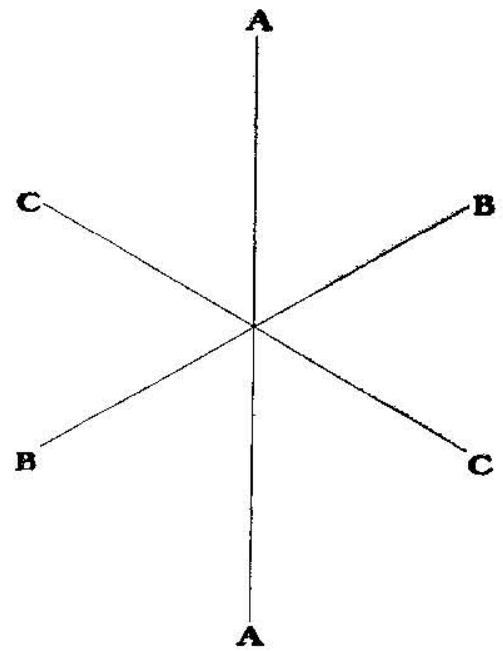

Tẹt-fig. 2: 
The most typical patterns are shown schematically in textfig. 1. In this figure, two DEBYE rings with eight intensity maxima are seen. Among the intensity maxima, aa are the most striking. This pattern is produced by the fibres in which the micelles are arranged in the direction parallel to the long axis of the cell. The photograph of this type is to be seen in the pl. 6, fig. 1. Textfig. 2 shows diagrammatically position of planes in cellulose crystals which produced text-fig. 1 . AA is fibre axis. The micelles which are oriented parallel to the long axis of the cell produce maxima aa in text-fig. 1 . $\mathrm{BB}$ and $\mathrm{CC}$ are crystal planes which produce maxima bc in text-fig. 1 . The second diffraction pattern of the pl. 6, fig. 2 appears when the micelles are oriented parallel to each other, but lying in a spiral inclined at an angle to the longitudinal axis of the wood fibre. The third pattern (pl. 6, fig. 3.) is explained by the fact that the cellulose micelles orientation varies somewhat from the parallel arrangement, since the fibrils lie in a spiral. The slope of the fibrils can be measured by the angles subtended by the more intense arcs. Lastly, the fourth pattern (pl. 6. fig. 4) is that in which only the DebYe rings are visible. This is due to the random orientation of micelles as in the cross section, but this type is very scarce. As to the relation of the wood fibre structure to the different species, the high density species usually reveal more nearly perfect orientation than those of lower density. In the diffraction patterns of spring and summer wood, DeBye rings are in general much more nearly perfect in the summer varieties. This is, of course, due to the microscopic structure and the difference in the thickness of the cell walls.

The breadth of the diffraction spots shows that the size of colloidal particles are important. In some species, the breadth of spot is greater than in others. This means a smaller micellar size which would indicate a shorter cellulose primary valence chain and fewer chains in a bundle.

This fact suggests a sure marking point concerning the identification of wood; minute conclusions are to be expected in the future.

The influence of lignin upon diffraction figure is considered to be negative. The sample "Kokutan" (Diospyros peregrina GÜRKE) has been used as having one of the highest known lignin contents. The photograph obtained shows a cellulose pattern, 
but the intensity is insignificant, for all its compactness. (See pl. ( fig. 20).

In the diffraction figures of the wood blocks which are obtained from the same cross section of the same tree, there are differences in the crystalline qualities. In general, the orientation of the micelles in the inner side of the tree (near to the centre of the year ring) is more perfect than that on the outer side (near to the bark) of the tree.

From the X-ray studies mentioned above, it is inferred that the diffraction figures of wood are attributable to the cellulose alone.

\section{DIFFRACTION FIGURES AND THE STRENGTH OF WOOD}

\section{(1) DebYe-ScherRer Rings and the Strength of Wood}

As mentioned in III, there are many variation in the diffraction patterns. In general the more the orientation of the micelles approaches perfection, the more the compactness of the wood increases.

Now by means of CLARK and Sisson's method, the intensity distribution along (002) ring on the diffraction figure may be known. In the first, the middle point of the equator of the diffraction figure is fixed on the film sliding rail of the microphotometer (the rail and drum are held in the state of motionless), then the intensity of the point of greatest strength on the (002) ring is read off directly on the galvanometer scale, and then the film is turned by 6 degrees around the fixed centre and the intensity of that point is read. Thus readings may be made every 6 degrees on the ring from the one end of the equator to the other, and a curve of intensity distribution on the (002) ring may be plotted. In this way, such a curve is obtained to each sample whose strength is previously measured. With these curves, the breadths of the diffraction line at the points of half maximum intensity are measured. Then the curve of the diffraction breadth against the strengths of the samples are plotted as shown in the text-fig. 3 .

From above experiment, it can be concluded that the narrower the diffraction breadth, the more the strength increases.

This method of strength measurement may be applied when the sample is not fitted for the testing machine measurement, as 
when the sample is very small or its shape is not good for ordinary test. In such cases, the LAUE photographs of the samples are first taken, then the intensity curve along (002) ring is drawn by the



method above mentioned and the diffraction breadth is measured, finally the strength is determined from the curve previously obtained.

\section{(2) Diffraction Figures for the Powder Patterns and the Strength of Wood}

Internal strain is determined by the "powder method". The sample is reduced to fine powder, before and after measuring its tensional strength. The diffraction depends upon the fact that in fine powder, the grains are arranged in an entirely chaotic manner. There should be enough particles in this array, turned at just the right angle to the incident primary beam of monochromatic $\mathrm{Fe}_{\alpha}$ ray.

$\mathrm{X}$-ray to produce a strong reflection from one set of parallel planes, other particles turned at another angle will produce reflection from another set of planes (the same set with many particle cooperating). Thus a beam passing through a powdered specimen will fall upon a narow film, which is bent in a casette on the circumference of a circle, at the centre of which the sample is placed as a series of concentric rings, each uniformly intense throughout, 

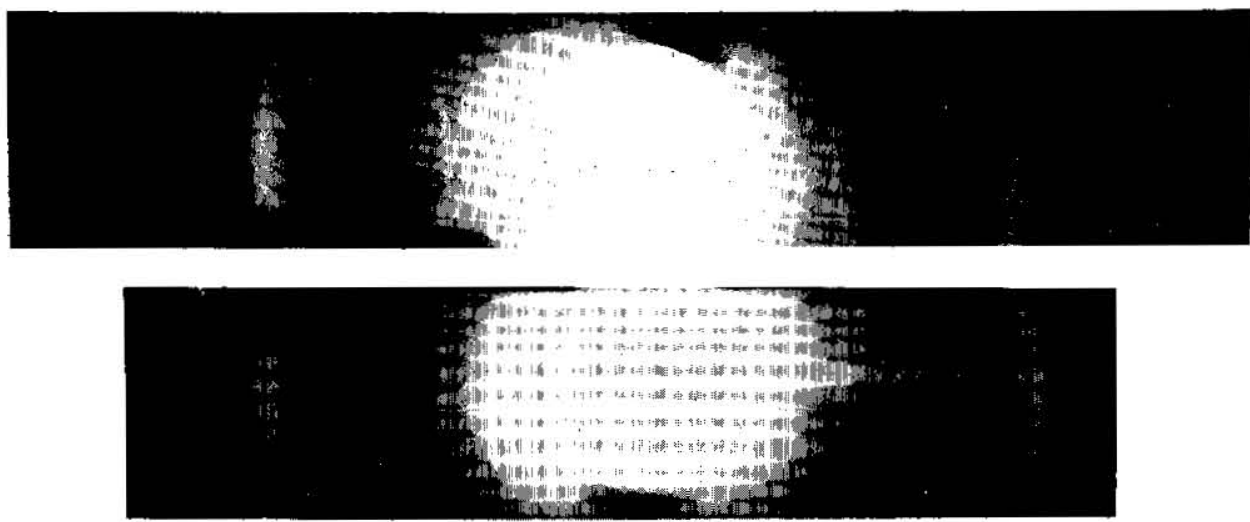

Text-fig. 4. Effect of strain in broadening diffraction interferences. Above unstrained; below strained.

and corresponding to one set of the planes of spacing $d$.

The powdered sample is placed in a fine capillary tube of glass.

Thus internal strain also manifests itself by a broadening of diffraction lines. planes.

In other words, the interference is less sharp for distorted

Broadening of the rings is also due to smallness of micelles, but we are not concerned with this case, since, the sizes of micelles are considered probably to be unchanged during the experiment.

\section{ON A NEW METHOD OF MEASURING THE INTERNAI STRAIN OF FIXED MATERIAL OF IARGE SIZE}

In the preceeding chapter, the $\mathrm{X}$-ray methods are described to measure the strength of material which can be made into thin layers or fine powders. But in cases where the material can not be treated thus, as in a bridge, a machine, a part of a building, or the like, the above methods are inapplicable. A method is proposed to measure the internal strain without breaking the material. The principle of this method is to use the interference ray with great angle, of the higher order, as opposed to the LAUE or DEBYESCHERRER method, which uses that of the lower order.

For the sensitive character to the film, X-rays of long wave length such as $\mathrm{Fe}_{\alpha}$ line is used. The arrangement of the apparatus 
is shown in text-fig. 5. In our experiment a small sample is used, but in an actual case, a large portion of fixed material could take the place of the sample. The X-rays which were made parallel by $\mathrm{Pb}$ slit, proceed to the material to be tested through a hole at the centre of a film which was covered by black paper, and then the reflected rays from the material show one or more radiation cones according to gitter constants of the polycrystalline materials and the



Text-fig. 5.

distance batween the film and the material, and these cones meeting the film and its cross section figure vertical to the cone axis form circular rings on the film. When a material composed of crystalline substance such as wood is distorted, the atom gitter of the constituent is also distorted. This distortion is already proved by DeHLinger and ARKEL, to be the broadening of $\mathrm{K}_{a}$ doublet. In our case, it is represented by the broadening of the breadth of diffraction rings.


Text-fig. 6. Effect of strain broadening diffraction interferences. Left strained; right unstrained. 
The width of the broadening is a function of the degree of gitter distortion. The broader the width of the rings becomes, the more the degree of the distortion increases. So a sufficient number of photographs are taken at different points of the material. Then the width of diffraction rings is measured, finally the distortions of the material are calculated.

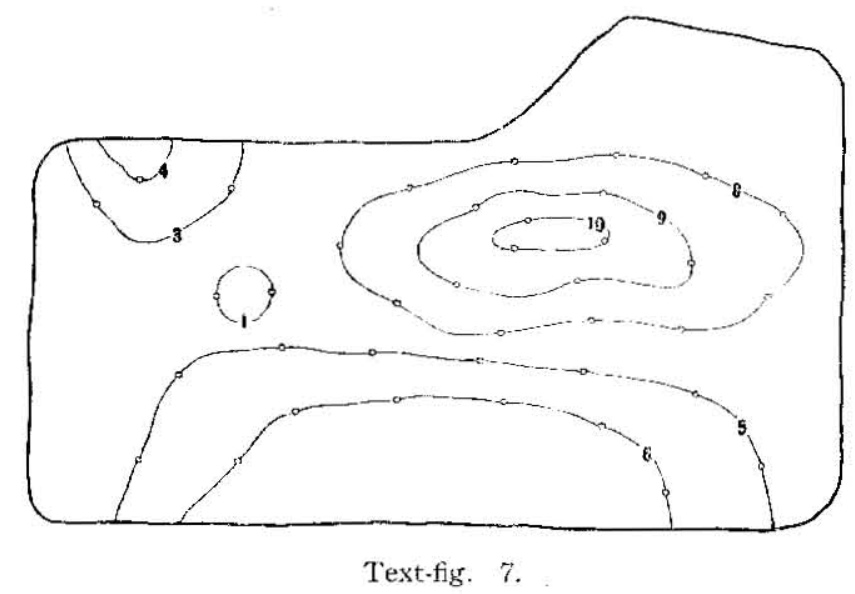

The model of distribution of strain of material solely from $\mathrm{X}$-ray diffraction patterns is shown in text-fig. 7 .

In this way, the distribution of the internal strain of the material may be ascertained without breaking it.

To compare this method with the LAUE method described in the last chapter (I), if the distance from the sample to the film in both cases is represented by $\mathrm{s}$, then by the LaUe method the radius $r$ for one of the wave lengths can be calculated by the following equation,

$$
\mathrm{r}=\mathrm{s} \tan 21,
$$

where $\theta$ is a glancing angle.

While by the reflection method,

$$
\mathrm{r}^{\prime}=\mathrm{s} \tan (180-2 \theta),
$$

where $\mathrm{r}^{\prime}$ is the radius in the reflection method.

If the wave length of the incident ray $i$ are equal to zero, then $\theta=0$. This means theoretically, that, in LAce's diagram, all 
the interference lines converge to zero, for a suitable small wave length. In other words, the interference line intersects the vertical axis at the origin of the coordinate system. For this, the condition $\cos i=\cos \eta$ is neccessary.

If $\lambda$ takes larger values, so, in the net plane, $\theta$ becomes larger providing that $\lambda$ and $\theta$ satisfy BRAGG's equation.

Let $A B$ be a rotating axis of the net plane of the crystal, which is perpendicular to the incident ray at the reflecting point, and $\partial$ is an angle between the vertical axis and the radius of the diffraction circle on the film.

When $\cos \theta=\cos \rho$ or $\cos \delta=1$ and $\grave{o}=0$, there still appear a diffraction figure, but at a certain maximum of $\lambda$, the interference figure disappears.



Text-fig. 8.

When $\theta>45^{\circ}$, the interference figure appears only in the reflection method.

In the interference figure, by means of polarcoordinates, the following relations are obtained. We define $\mathrm{r}$ as radiusvector and

and

$$
\varphi=90-i=\arcsin \frac{\cos \theta}{\cos \theta},
$$

$$
\begin{aligned}
& \mathrm{r}=\frac{2 \mathrm{~s} \tan \theta}{1-\tan ^{2} \theta}, \\
& \cos \theta=-\cos \theta \\
& \cos \delta^{-}
\end{aligned}
$$

therefore 


$$
\mathrm{r}=\frac{2 \mathrm{~s} \omega \rho \gamma \omega^{2} \varphi-\omega^{2} \rho}{2 \omega^{2} \theta-\sin ^{2} \varphi}
$$

\section{X-RAY ABSORPTION OF WOOD}

The fact that the X-ray is absorbed in wood in accordance with a definite law is, of coursc, of very great practical importance. Differential absorption by heterogeneous matter of varying density is the fundamental basis of the entire science of radiography, in the examination, for example, of detection of the defects which exist in wood.

When a monocromatic X-ray beam having the intensity I traverses normally through very thin sheets of wood of a thickness $\mathrm{dx}$, the intensity in the beam emerging from the wood is decreased by an amount $\mathrm{dI}$, so that the following relationship holds,

$$
\frac{\mathrm{dI}}{\mathrm{I}}=-\mu \mathrm{dx},
$$

$/$ depending on the wave length of the incident beam and on the absorber. It is seen to have the dimensions of a reciprocal length and hence is often referred to as the linear absorption coefficient.

We may, however, prefer to think in terms of the fraction of the beam removed by each atom which it traverses. Let us imagine that the material traversed consists of one kind of atom only. We should then write

$$
\frac{\mathrm{dI}}{\mathrm{I}}=-\mu_{\mathrm{a}} \mathrm{dn}
$$

where $\mathrm{dn}$ is the number of atoms in the path of the beam as it passes through the absorber, and $/{ }_{\alpha}$ is the atomic absorption coefficient. If we consider a beam of $1 \mathrm{~cm}^{2}$. cross section, we see that

$$
\mathrm{dn}=\frac{N_{\rho} \mathrm{dx}}{\mathrm{A}}
$$

where $\rho$ is the density of the material, $A$ the atomic weight, and $\mathrm{N}$ the Avogadro number; the quotient $\mathrm{A} / \mathrm{N}$ representing the mass of an atom in the material. By a comparison of the preceeding equations, it is seen that

$$
\mu_{\mathrm{a}}=\mu \frac{\mathrm{A}}{\rho-1}
$$


The mass absorption coefficient, $p_{\mathrm{m}}$, refers to the power diverted per gram of material traversed by the beam.

In this sense, we write

$$
\mathrm{dI}=-/{ }_{\mathrm{m}} \mathrm{dm},
$$

where $\mathrm{dm}$ is the number of grams in the path of the atom. But

and therefore

$$
\mathrm{dm}=\rho \mathrm{dx},
$$

$$
\mu_{\mathrm{mI}}=\mu / \rho=\mu_{\mathrm{a}}(\mathrm{N} / \mathrm{A})
$$

This expression indicates that the mass absorption coefficient is simple N/A times the atomic coefficient.

In a compound, whose formula may be

$$
\mathrm{X}_{\mathrm{x}}, \mathrm{Y}_{\mathrm{y}}, \mathrm{Z}_{z} \ldots \ldots \ldots \ldots \ldots,
$$

it is typical of the behavior of the X-ray that a molecular absorption coefficient $n^{\prime \prime m o l}$ may be used which is defined by additive relations involving the atomic absorption coefficients of the constituents of the compound.

Thus

$$
\mu_{\text {mol. }}=-\frac{\mathrm{A}}{\mu_{\mathrm{N}}} \mu=\mathrm{x}\left(\mu_{\mathrm{a}}\right)_{\mathrm{x}}+\mathrm{y}\left(\mu_{\mathrm{a}}\right)_{\mathrm{y}}+\mathrm{z}\left(\mu_{\mathrm{a}}\right)_{2} \ldots \ldots \ldots \ldots \ldots \ldots
$$

where $\left(\mu_{\mathrm{a}}\right)_{\mathrm{X}}$ is the atomic absorption coefficient of the atom $\mathrm{X}$ for the wave length in question.

If $I_{0}$ is the power incident upon an absorber; and $I$ is the transmitted power, integration of the above differential expressions gives

$$
\mathrm{I}=\mathrm{I}_{0} \mathrm{e}^{-\mu_{\mathrm{x}}}=\mathrm{I}_{0} \mathrm{e}^{-u_{\mathrm{m}} p \mathrm{x}}=\mathrm{I}_{0} \mathrm{e}^{-y_{i \mathrm{i}}(\omega \mathrm{N} / A) \mathrm{x}}
$$

where $\mathrm{x}$ is the thickness of the absorber in $\mathrm{cm}$.

In the case of wood, the absorption coefficients depend upon its constituents, or cellulose, hemicellulose and lignin.

By the help of the expression (1), we can calculate the coefficient of absorption.

To this end, we must know in the first place, the percentage of content of $\mathrm{C}, \mathrm{H}, \mathrm{O}$ in those constituents, 
The percentage of cellulose, $\mathrm{C}, \mathrm{H}$ and $\mathrm{O}$ content for cellulose is as follows

$$
\begin{aligned}
& \text { C: } \quad 44 \%, \\
& \text { H: } \quad 6 \%, \\
& \text { O: } 50 \% .
\end{aligned}
$$

For the hemicellulose, such as hexosane, pentosane, hexopentosane, and polysaccharide, the percentages of content of $\mathrm{C}, \mathrm{H}$ and $\mathrm{O}$ are similar to of cellulose.

For lignin, the percentages of content are assumed as follows,

$$
\begin{aligned}
& \text { C: } 66 \%, \\
& \text { H: } 6 \%, \\
& \text { O: } 28 \% .
\end{aligned}
$$

To these constituents, there must be added a few accessary constituents, such as turpentine, pigments, fat, resin, nitrogen involving substances and mineral matters, but their quantities are negligible for the first approximation.

The absorption coefficient of wood is then given by the following equation.

$$
\left(\frac{\not L}{\rho}\right)_{\text {wond }}=\left[\left(\frac{\not L}{\rho}\right)_{\text {cell. }} \mathrm{C}_{\text {ccll. }}+\left(\frac{\not \prime}{\rho}\right) \mathrm{C}_{\text {lign. }}\right] \mathrm{g}
$$

where $\left(\frac{\mu}{\rho}\right)_{\text {cefl. }}$ is the calculated cellulose absorption coefficient and $\left(\begin{array}{c}\mu \\ \rho\end{array}\right)_{\text {ligrn. }}$ is the calculated lignin absorption coefficient. $C_{\text {ccil. }}$ and $\mathrm{C}_{\text {lign. }}$ represent the percentages of content by weight of cellulose and lignin in the wood.

$g$ means the weight percentage of wood substance to the net density of wood, which is equal to the ratio of $\mathrm{c} / \mathrm{G}$.

The value of $c$ vary according to the species, namely,

and $G$ is 1.56 .

$$
\begin{aligned}
& c_{N}=0.51, \\
& c_{S}=0.57, \\
& c_{H}=0.75,
\end{aligned}
$$

Then the values of $\mathrm{g}$ are as follows,

$$
\begin{aligned}
& \mathrm{g}_{\mathrm{N}}=0.32 \\
& \mathrm{~g}_{\mathrm{S}}=0.36 \\
& \mathrm{~g}_{\mathrm{H}}=0.84
\end{aligned}
$$


The calculated values of $\frac{\mu}{\rho}$ and $"$ of cellulose and lignin for the wave length of $1.934 \AA$ are

$\begin{array}{lll}\text { Cellulose } & 14.89 & 22.34 \\ \text { Lignin } & 11.98 & 17.97 .\end{array}$

Besides the theoretical method above mentioned, by the use of the MARTIUs's ionemeter, the absorption coefficients of many species were measured experimentally.

The results are given in Table II.

Table II

No. Japanese name

Latin name

$\frac{\mu}{\rho} \quad \mu$

GYMNOSPERMAE

Ginkgoaceae

1 Ityô Ginkgo biloba

$3.63 \quad 5.67$

\section{CONIFERAE}

Podocarpaceae

2 Inumaki

Podocarpus macrophyllus D. DON 4.296 .69

Taxaceae

$\begin{array}{ll}3 & \text { Itii } \\ 4 & \text { " } \\ 5 & \text { Kaya } \\ 6 & \text { " }\end{array}$

Taxus cuspidata $\mathrm{S}$. et $\mathrm{Z}$.

$3.67 \quad 5.73$

, " , , ", ,

$3.33 \quad 5.19$

Torreya mucifera $\mathrm{S}$. et $\mathrm{Z}$.

$\begin{array}{ll}4.10 & 6.39\end{array}$

,

$5.02 \quad 7.83$

\section{Pinaceae}

7 Momi

Abies firma S. et $Z$.

$4.29 \quad 6.69$

8 ,

" , , , , ,

$3.67 \quad 5.73$

9 Aotodomatu

Abies Mayriana Mryare et Kudó

$2.98 \quad 4.65$

10 Tôsirabe

Abies nephrolepis MAX.

$3.75 \quad 5.85$

11 Bêmomi

Abies nobilis LINDLEY

$\begin{array}{ll}3.85 & 6.00\end{array}$

12

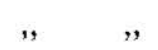

$3.52 \quad 5.49$ 


\begin{tabular}{|c|c|c|c|c|}
\hline 13 & Todomatu & Abies sachalinensis MAST. & 3.64 & 5.68 \\
\hline 14 & Sirabe & Abies Veitchii LINDL. & 3.17 & 4.95 \\
\hline 5 & & ", & 3.12 & 4.86 \\
\hline 6 & $\begin{array}{l}\text { Siberia- } \\
\text { karamatu }\end{array}$ & Larix dahurica TuRCz. & 4.81 & .50 \\
\hline 7 & Karamatu & Larix Kaempferi SARG. & 3.65 & 70 \\
\hline 18 & , & , & 3.81 & \\
\hline & $\begin{array}{l}\text { Karahuto- } \\
\text { karamatu }\end{array}$ & Larix kurilensis MAYR & 3.84 & \\
\hline & " & , & 4.42 & 90 \\
\hline 21 & Tyôsenkaramatu & Larix olgensis A. Henry & 4.06 & \\
\hline & ", & , & 4.52 & \\
\hline 23 & Tôhi & Picea hondoensis MAYR & 4.31 & \\
\hline 64 & Ezomatu & Picea jezoensis CARR. & 4.92 & \\
\hline & $"$ & " & 3.88 & \\
\hline & , & , & 3.19 & \\
\hline 27 & , & $"$ & 3.10 & \\
\hline 8 & Tyôsenharimomi & Picea koraiensis NaKat & 3.76 & 86 \\
\hline 29 & Bètôhi & Picea sitchensis CARRIERE & 4.13 & \\
\hline 0 & Akamatu & Pinus densiflora S. et $Z$. & 4.01 & \\
\hline 31 & & $, ", \quad$, & 3.85 & 0 \\
\hline 32 & Tyôsenmatu & Pinus koraiensis S. et $\mathrm{Z}$. & 3.75 & \\
\hline 33 & $"$ & $, ", \quad$, & 3.65 & \\
\hline & $"$ & $" \quad " \quad "$ & 5.06 & \\
\hline & ", & $", \quad$, & 3.86 & \\
\hline 36 & Ryûkyûmatu & Pimus huchuensis MAYR & 5.00 & \\
\hline 7 & Monticola-Matu & Pinus monticola D. DoN & 3.40 & \\
\hline 38 & Himekomatu & Pinus parviflora $\mathrm{S}$, et $\mathrm{Z}$. & 3.54 & \\
\hline 39 & & $", "$, & 3.42 & 5.34 \\
\hline 40 & Ôsyûakamatu & Pinus silvestris $\mathrm{I}$. & 4.94 & 7.71 \\
\hline 41 & Kuromatu & Pinus Thunbergii PARL. & 4.79 & \\
\hline 42 & Togasawara & Psendotsuga japonia BeIss. & 3.73 & 5. \\
\hline 43 & Bêmatu & Pseudotsuga taxifolia BRITT. & 4.23 & 6.60 \\
\hline 4 & ", & , & 3.56 & \\
\hline 45 & Kôyamaki & Sciadopitys verticillata S. et $Z$. & 3.46 & \\
\hline 46 & , & $" \quad, \quad$, & 3.65 & 5.70 \\
\hline 47 & Bêtuga & Tsuga heterophylla SARGENT & 4.77 & \\
\hline 48 & Tuga & Tsuga Sieboldii CARR. & 4.90 & 7.65 \\
\hline 49 & , &  & 3.71 & \\
\hline
\end{tabular}




\section{Taxodiaceae}

50 Sugi

$\begin{array}{llll}\text { Cryptomeria japonica } \text { D. DoN } & 3.67 & 5.73\end{array}$

51 ,

52 Yakusugi

53 Nikkôsugi

54 Zindaisugi

55 Akasugi

56

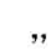

57 Taiwansugi

58

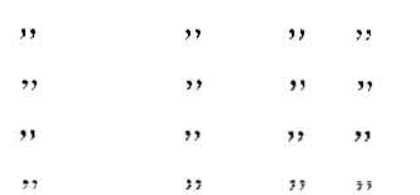

4.637 .23

$4.17 \quad 6.51$

$3.31 \quad 5.16$

Sequoia sempervirens ENDL. $\quad 3.625 .64$

$\begin{array}{ccrr}\text { " } " & 3.31 & 5.16 \\ \text { Taiwania cryptomerioides HaYATA } & 3.67 & 5.73 \\ ", \quad " & 4.03 & 6.29\end{array}$

\section{Cupressaceae}

59 Benihi

Chamaecyparis formosensis Matsum.

$3.52 \quad 5.49$

60 ,

61 Bèhinoki

Chamaecyparis Lawsoniana PARLATORE

$3.65 \quad 5.70$

$3.96 \quad 6.18$

62 "

63 Bêsawara

Chamaecyparis nootkatensis SUDWORTH

$4.37 \quad 6.81$

64 Hinoki

Chamaecyparis obtusa $\mathrm{S}$. et $Z$.

$3.73 \quad 5.82$

65 "

66 Taiwanhinoki

".

$3.85 \quad 6.00$

Chamaecyparis obtusa form. formosana HAYATA

$3.65 \quad 5.70$

67

68 Sawara

Chamaecyparis pisifera S. et Z.

$4.27 \quad 6.66$

$3.67 \quad 5.72$

69 ,

", ", ,

$3.70 \quad 5.77$

$3.69 \quad 5.76$

70 Byakusin

Juniperus chinensis L.

$4.42 \quad 6.90$

Juniperus rigida $\mathrm{S}$. et $\mathrm{Z}$.

$4.08 \quad 6.36$

72 Bêsugi

Thuja plicata D. DON

$\begin{array}{ll}4.58 & 7.14\end{array}$

73 ,

" " " ,

$3.10 \quad 4.83$

74 Hiba

Thujopsis dolabrata $\mathrm{S}$. et $\mathrm{Z}$.

$4.18 \quad 6.52$

75 ,

76 ,

77 Nezuko



$4.19 \quad 6.54$

\begin{tabular}{ll}
$2.81 \quad 3.83$ \\
\hline
\end{tabular}

Thuja Standishii CARR.

$3.83 \quad 5.98$

78

,

$3.56 \quad 5.55$ 
79 Syônanboku

Lihoredrus formosana FLORIN $\quad 3.85 \quad 6.00$

80

,

\section{MONOCOTYLEDONEAE}

\section{Palmae}

81 Birô

Livistonia subglobosa MARTIUS

$2.84 \quad 9.40$

82 ,

83 Syuro

Trachycarpus excelsus WENDL.

$3.57 \quad 8.37$

6.159 .60

\section{DICOTYLEDONEAE}

\section{Archichlamydeae}

\section{Salicaceae}

84 Doroyanagi

Populus Maximowiczii A. Henry 3.655 .70

85

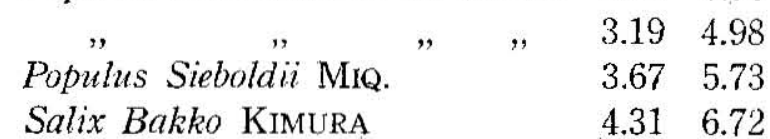

87 Bakkoyanagi

Salix Bakko KIMURA

$4.31 \quad 6.72$

\section{Juglandaceae}

88 Mansyûkurumi Juglans mandshurica MAX. $\quad 4.276 .66$

89 Onigurumi Juglans Sieboldiana MaXIm. $\quad 4.00 \quad 6.24$

$90 \quad$ " " $\quad$ " $\quad 4.817 .50$

91 Tyôsengurumi Juglans regia var. sinensis C.DC. $4.73 \quad 7.38$

92 Sawagurumi Pterocarya rhoifolia S. et $Z$. 4.226 .59

\section{Betulaceae}

93 Hannoki

Alnus japonica $\mathrm{S}$. et $Z$.

$3.81 \quad 5.94$

94 ,,

,

, , , ,

$\begin{array}{ll}4.10 & 6.39\end{array}$

95 Yamahannoki

Almus tinctoria SARGENT

$3.79 \quad 5.91$

96 Yogusominebari

Betula carpinifolia $\mathrm{S}$. et $Z$.

5.158 .04

97

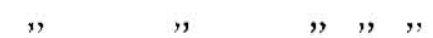

$4.23 \quad 6.60$

$98 \quad$,

99 Ono'ore

, ", ", ", ,

$\begin{array}{ll}3.85 & 6.00\end{array}$

Betula Schmidtii REGEL

$3.88 \quad 6.05$

100 Sirakanba

Betula Tauschii KoIDz.

$4.31 \quad 6.72$

101

" "

$4.73 \quad 7.38$

102 Kabazakura

Betula sp.

$4.65 \quad 7.26$

103 Inuside

Carpinus Tschonoskii MAXIM.

$\begin{array}{ll}5.11 & 7.97\end{array}$ 


\section{Fagaceae}

104 Kuri

105 ,"

106 Buna

107

108 Amigasi

109 Akagasi

110

111 Kunugi

112

113 Mizunara

114

115 Kasiwa

116 Itiigasi

117

118 Mongorinara

119

120 Sirakasi

121

122 Siinoki

123 ",

124. Mukunoki

125 Enoki

126 Harunire

127

128 Kobunire

129

130 Ohyônire

131 Keyaki

132
Castanea crenata $\mathrm{S}$. et $\mathrm{Z}$.

$\begin{array}{ll}4.17 & 6.51\end{array}$

$4.81 \quad 7.50$

Fagus crenata BL. $\quad 4.67 \quad 7.29$

$4.80 \quad 7.49$

Lithocarpus amygdalifolia HAYATA 3.856 .00

Quercus acuta THUNB.

$\begin{array}{ll}6.23 \quad 9.72 \\ 5.54 & 8.64\end{array}$

$5.54 \quad 8.64$

Quercus acutissima CARR.

$3.90 \quad 6.09$

$\begin{array}{ll}5.71 & 8.91\end{array}$

$3.69 \quad 5.75$

$4.47 \quad 6.98$

$5.45 \quad 8.50$

Quercus dentata THUNB.

Quercus gilva BL.

$5.19 \quad 8.10$

$\begin{array}{ll}5.35 & 8.34\end{array}$

Quercus mongolica FiscH.

$4.37 \quad 6.81$

$\begin{array}{ll}4.77 & 7.44\end{array}$

$4.73 \cdot 7.38$

$5.12 \quad 7.98$

$4.46 \quad 6.96$

$5.58 \quad 8.70$

\section{Ulmaceae}

Aphananthe aspera PLANCH. $\quad 5.198 .16$

Celtis sinensis PERS.

$3.75 \quad 5.85$

Ulmus Davidiana var. japonica NAKAI

$\begin{array}{ll}3.71 & 5.79\end{array}$

$4.42 \quad 6.89$

Ulmus Davidiana var. japonica

f. suberosa NAKAI

$4.02 \quad 6.27$

$4.62 \quad 7.21$

Ulmus laciniata "MARR

$4.90 \quad 7.65$

Zelkowa serrata MAKINO

$4.35 \quad 6.78$

$5.19 \quad 8.10$

\section{Moraceae}

133 Gazyumaru

134

135 Yamaguwa
Ficus retusa L.

$4.44 \quad 6.93$

$4.99 \quad 7.78$

Morus bombycis KorDz. 


\section{Cercidiphyllaceae}

136 Katura

Cercidiphyllum japonicum S. et Z. $4.04 \quad 6.30$

\section{Magnoliaceae}

138 Hantenbolu

Liriodendron tulipifera $\mathrm{L}$.

$5.01 \quad 7.82$

139 Hônoki

Magnolia obovata THunB.

$3.51 \quad 7.04$

140

Magnolia salicifolia MАХІм.

$4.48 \quad 6.99$

141 Tamusiba

Michelia contpressa MAXæM.

$5.00 \quad 7.80$

142 Ogatamanoki

143

\section{Lauraceae}

144 Kusu

$145 \quad "$

146 Tabu

147 "

148 Isunoki

149 ”

150 Amerika-Suzukakenoki

\section{Cinnamomum Camphora Sieb.}

$4.38 \quad 6.84$

Machilus Thunbergii S. et Z̈.

$4.98 \quad 7.77$

$3.92 \quad 6.12$

"

", "

\begin{tabular}{ll}
$5.40 \quad 8.43$ \\
\hline
\end{tabular}

\section{Hamamelidaceae}

Distylium racemosum S. et $Z$. $\quad 4.65 \quad 7.26$ "

\section{Platanaceae}

Platanus occidentalis L.

$3.29 \quad 4.13$

\section{Rosaceae}

151 Sakura

Prumus sp.

$3.92 \quad 7.80$

152 ,

153 Syûrizakura

Prumus "Ssioni Fr. SchM.

$2.88 \quad 5.65$

$\begin{array}{ll}4.54 & 7.08\end{array}$

\section{Leguminosae}

154 Tagayasan

Cassia siamea LaM.

$4.75 \quad 5.33$
5

Dipterocarpus sp.

\begin{tabular}{ll}
$5.92 \quad 9.24$ \\
\hline
\end{tabular}

Maackia amurensis var. Buergeri SCHNEID.

$4.50 \quad 7.02$

156 Inuenzyu

157
"
$3.18 \quad 5.05$ 
158 Sitan

159 Karin

160 Niseakasiya
Pterocarpus indicus WILD.

Pterocarpus macrocarpus KURZ

Robinia pseudacacia $\mathrm{L}$.

161 Yusôboku

Guajacum officinale $\mathrm{L}$.

162 Yuzu

163 Amûrukihada

164 Kihada

165 Sinzyu

166 Sendan

167 "

168 Akagi

169

"

170 Tuge

171

"

172 Urusinoki

173

",

174 Aohada

175 Momizi

176

Buxaceae

$"$

$"$

,$\quad$,

\section{Anacardiaceae}

Rhus verniciflua STOKES

"

,

\section{Aquifoliaceae}

Ilex macropoda MiQueL

\section{Aceraceae .}

Acer palmatum THUNB.

\section{Zygophyllaceae}

\section{Rutaceae}

Citrus Aurantium subsp. Junos

$\begin{array}{ll}4.32 & 5.12\end{array}$

$4.17 \quad 4.83$

$4.69 \quad 7.32$

$4.86 \quad 5.80$

$4.48 \quad 6.99$ MaKino

Phellodendron amurense RUPR.

Phellodendron japonicum MAX.

\section{Meliaceae}

Ailanthus glandulosa DesF.

Melia Azedarach var. japonica MAKINO

$5.40 \quad 8.43$

$\begin{array}{ll}3.52 & 5.49\end{array}$

$4.23 \quad 6.60$

$\begin{array}{ll}3.71 & 5.79\end{array}$

$4.39 \quad 6.85$

\section{Euphorbiaceae}

Bischoffia javanica BL.

$4.10 \quad 6.39$

$3.50 \quad 5.17$

Buxus japonica Muell.-ARg. $\quad 5.83 \quad 9.09$

$3.42 \quad 6.03$

$5.06 \quad 7.89$

$2.95 \quad 4.77$

$4.81 \quad 7.50$

$\begin{array}{ll}4.62 \quad 7.20 \\ 3.66 & 4.55\end{array}$

$3.66 \quad 4.45$ 


\section{Hippocastanaceae}

177 Toti

178 "

179 Kenponasi
Aesculus turbinata BL.

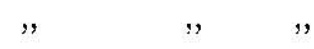

\section{Rhamnaceae}

Hovenia dulcis THunB.

Tiliaceae

180 Amûrusinanoki Tilia amurensis Kom.

181 Sinanoki

182 ”

Tilia japonica SINK.

"

\section{Bombacaceae}

$18 \dot{3}$ Barusa

Ochroma boliviana ROWLEE
$4.38 \quad 6.84$

$2.93 \quad 4.78$

\section{$4.73 \quad 7.38$}

$3.58 \quad 5.58$

$4.73 \quad 7.38$
-.58

$2.87 \quad 4.77$

$1.09 \cdot 1.34$

\section{Theaceae}

184 Yamatubaki

185

186 Natutubaki

187 Mokkoku

188

"

189 Tamana

190 Hukugi

191 Siro Lauan

192 Aka Lauan

193 Harigiri

$194 \quad$ "

195 "

196 Mizuki

197
Camellia japonica var. spontanea MAKINO

$\begin{array}{ll}6.23 \quad 9.72 \\ 3.45 & 4.62\end{array}$

",

, "

$3.45 \quad 4.62$

Stewartia Pseudocamellia Maxim. $5.44 \quad 8.49$

Ternstroemia Mokof NAKAI

$5.45 \quad 8.50$

$3.42 \quad 4.52$

Guttiferae

Calophyllum Inophyllum $\mathrm{L}$.

$4.12 \quad 6.42$

Garcinia spicata Ноок. f.

$3.43 \quad 4.19$

\section{Dipterocarpaceae}

Pentacme controrta M. \& R. $\quad 5.04 \quad 7.86$

Shorea negrosensis Foxw. $\quad 3.856 .00$

Araliaceae .

Kalopanax pictum NAKAI $\quad 5.73 \quad 5.82$

$\begin{array}{llll} & & & \end{array}$

$\begin{array}{lllll} & & & & \end{array}$

Cornaceae

Cormus controversa Hemsl. $\quad 3.88 \quad 6.06$

$3.45 \quad 4.06$ 


\section{Metachlamydeae}

\section{Ebenaceae}

\section{Aokokutan \\ 199 Yamagaki \\ 200 Kokutan}

201 Egonoki

202

".

203 Siozi

$204^{\circ}$,

205 Toneriko

206 ,

207 Yatidamo

208 "

$209 \quad$ "

210 Hiiragi

211 Teak

212 Kiri

213 ”
Diospyros chloroxylon RoyB.

Diospyros Kaki var. silvestris MaKino

Diospyros peregrina GüRKE

\section{Styracacecae}

Styrax japonica S. et Z.

$4.02 \quad 6.27$

$3.34 \quad 4.97$

\section{Oleaceae}

Fraxinus commemoralis KolD\%. $3.94 \quad 6.15$

$3.60 \quad 4.35$

Fraxinus japonica Bu,ume $\quad 4.23 \quad 6.60$

$\begin{array}{llll}, " \quad, \quad & 3.42 & 5.30\end{array}$

Fraxinus mandshurica RUPR. $\quad 4.81 \quad 7.50$

, " $\quad, \quad 3.42 \quad 4.21$

$\begin{array}{ll}4.38 & 6.84\end{array}$

Osmanthus ilicifolius STANDISH $\quad 4.81 \quad 7.50$

Verbenaceae

Tectona grandis L. $\mathrm{f}$.

$4.31 \quad 6.72$

\section{Scrophulariaceae}

Paulownia tomentosa STEud. $\quad 3.815 .94$

The comparison of calculated values from the equation (2) and measured values is described in the following.

In the experiment, an X-ray of wave length $1.94 \AA$ was used, voltage was about $50 \mathrm{KV}$. and the current $4-8$ miliamperes.

\begin{tabular}{|c|c|c|}
\hline Hard wood & Soft wood & $\begin{array}{l}\text { Needle leaved } \\
\text { wood }\end{array}$ \\
\hline $\begin{array}{ll}\mu_{\text {calc. }} & \mu_{\text {obs }} \\
10.71 & 9.64\end{array}$ & $\begin{array}{cc}\mu_{\text {calc. }} & \mu_{\text {obs }} \\
8.04 & 7.43\end{array}$ & $\begin{array}{ll}\text { Fcalce }^{\text {cals }} & u_{\text {obs }} \\
7.14 & 6.50\end{array}$ \\
\hline
\end{tabular}


Table III

\begin{tabular}{|c|c|c|c|c|}
\hline \multirow{2}{*}{$(\hat{\Lambda})$} & \multicolumn{2}{|c|}{ Cellulose } & \multicolumn{2}{|c|}{ Lignin } \\
\hline & ! & p. & $\frac{i}{i}$ & 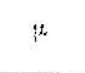 \\
\hline 0.1 & 0.153 & 0.230 & 0.149 & 0.224 \\
\hline 0.2 & 0.192 & 0.288 & 0.193 & 0.285 \\
\hline 0.3 & 0.231 & 0.347 & 0.225 & 0.338 \\
\hline 0.4 & 0.304 & 0.456 & 0.284 & 0.426 \\
\hline 0.5 & 0.426 & 0.639 & 0.381 & 0.572 \\
\hline 0.6 & 0.609 & 0.913 & 0.526 & 0.789 \\
\hline 0.7 & 0.866 & 1.299 & 0.783 & 1.175 \\
\hline 0.8 & 1.361 & 2.042 & 1.120 & $1.68)$ \\
\hline 0.9 & 1.629 & 2.444 & 1.346 & 2.019 \\
\hline 1.0 & 2.250 & 3.375 & 1.730 & 2.600 \\
\hline 1.1 & 2.804 & 4.206 & 2.278 & 3.417 \\
\hline 1.2 & 3.554 & 5.331 & 2.922 & 4.383 \\
\hline 1.3 & 4.496 & 6.744 & 3.636 & 5.454 \\
\hline 1.4 & 5.806 & 8.709 & 4.656 & 6.984 \\
\hline 1.5 & 7.326 & 10.989 & 5.850 & 8.820 \\
\hline 1.6 & 8.739 & 13.109 & 6.983 & 10.475 \\
\hline 1.7 & 10.27 & 15.41 & 8.24 & 12.36 \\
\hline 1.8 & 12.16 & 18.24 & 9.74 & 14.61 \\
\hline 1.9 & 14.52 & 21.78 & 10.96 & 16.44 \\
\hline 2.0 & 17.07 & 25.62 & 13.60 & 20.40 \\
\hline 2.1 & $19.6 \overline{5}$ & 29.48 & 15.65 & 23.48 \\
\hline 2.2 & 22.32 & 33.48 & 17.73 & 26.60 \\
\hline 2.3 & 23.85 & 35.78 & 19.40 & 29.10 \\
\hline 2.4 & 26.32 & 39.48 & 21.30 & 31.95 \\
\hline 2.5 & 30.31 & 45.46 & 24.65 & 36.98 \\
\hline
\end{tabular}


Table IV

\begin{tabular}{|c|c|c|c|c|c|c|}
\hline \multirow{2}{*}{$\therefore(\ddot{A})$} & \multicolumn{2}{|c|}{ Hard Wood } & \multicolumn{2}{|c|}{ Soft Wood } & \multicolumn{2}{|c|}{ Needle Leaved Wood } \\
\hline & 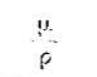 & $\mu$ & $\frac{y .}{6}$ & p. & $p$ & 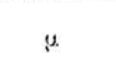 \\
\hline 0.1 & 0.048 & 0.075 & 0.055 & 0.085 & 0.073 & 0.114 \\
\hline 0.2 & 0.061 & 0.095 & 0.071 & 0.111 & 0.094 & 0.146 \\
\hline 0.3 & 0.074 & 0.115 & 0.083 & 0.129 & 0.110 & 0.171 \\
\hline 0.4 & 0.096 & 0.150 & 0.108 & 0.168 & 0.144 & 0.225 \\
\hline 0.5 & 0.133 & 0.207 & 0.150 & 0.234 & 0.200 & 0.312 \\
\hline 0.6 & 0.190 & 0.296 & 0.213 & 0.333 & 0.284 & 0.444 \\
\hline 0.7 & 0.292 & 0.424 & 0.333 & 0.479 & 0.408 & 0.636 \\
\hline 0.8 & 0.441 & $0 . € 88$ & 0.496 & 0.774 & 0.661 & 1.301 \\
\hline 0.9 & 0.535 & 0.835 & 0.602 & 0.939 & 0.803 & 1.253 \\
\hline 1.0 & 0.982 & 1.532 & 0.737 & 1.149 & 0.982 & 1.5321 \\
\hline 1.1 & 0.864 & 1.348 & 0.972 & 1.516 & 1.295 & 2.020 \\
\hline 1.2 & 1.097 & 1.711 & 1.234 & 1.925 & 1.645 & 2.566 \\
\hline 1.3 & 1.312 & 2.047 & 1.557 & 2.429 & 2.075 & 3.237 \\
\hline 1.4 & 1.784 & 2.783 & 2.007 & 3.131 & 2.676 & 4.175 \\
\hline 1.5 & 2.218 & 3.460 & 2.495 & 3.892 & 3.327 & 5.190 \\
\hline 1.6 & 2.684 & 4.187 & 3.020 & 4.711 & 4.026 & 6.281 \\
\hline 1.7 & 3.150 & 4.914 & 3.544 & 5.529 & 4.725 & 7.371 \\
\hline 1.8 & 3.736 & 5.828 & 4.203 & 6.557 & 5.604 & 8.742 \\
\hline 1.9 & 4.227 & 6.594 & 4.755 & 7.418 & 6.340 & 9.890 \\
\hline 2.0 & 5.240 & 8.174 & 5.895 & 9.196 & 7.860 & 12.262 \\
\hline 2.1 & 6.032 & 9.411 & 6.786 & 10.586 & 9.048 & 14.115 \\
\hline 2.2 & 6.845 & 10.678 & 7.701 & 12.014 & 10.268 & 16.018 \\
\hline 2.3 & 7.603 & 11.861 & 8.553 & 13.343 & 11.405 & 17.792 \\
\hline 2.4 & $8.10 \mathrm{t}$ & 12.638 & 9.114 & 14.218 & 12.152 & 18.957 \\
\hline 2.5 & 14.003 & 21.844 & 10.502 & 16.383 & 9.335 & 14.563 \\
\hline
\end{tabular}




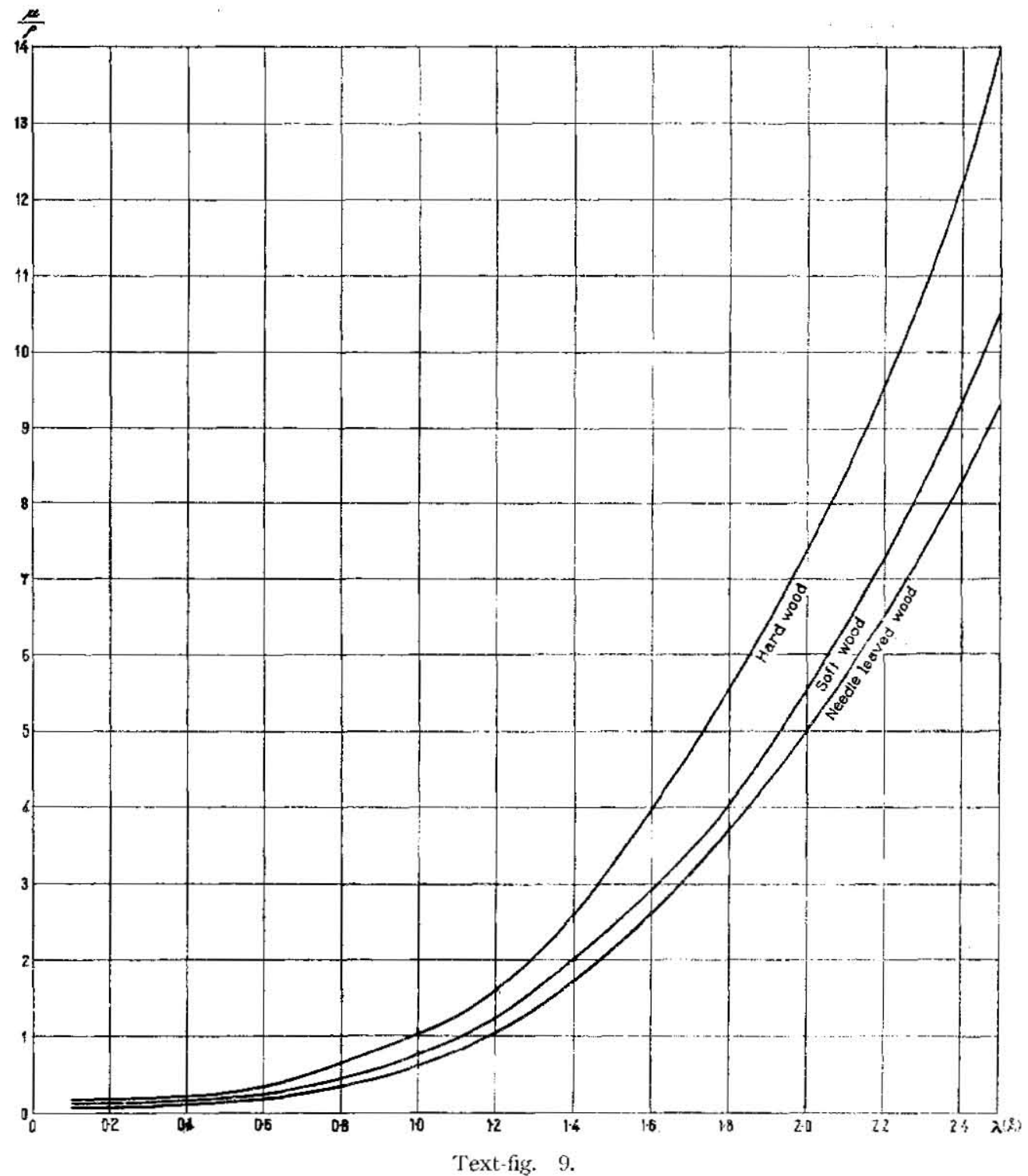


For practical use, the values of $\frac{\mu}{\mu}$ and $\mu$ for the various wave lengths are calculated by equation (2), and tabulated in Table III and IV and presented as a graph as text-fig. 9.

The author desires to express his thanks to Prof. S. Katayama whose kindness has made possible the completion of this work. He wishes also to thank Prof. U. Yoshida of the Kyôto Imperial University for his incessant guidance, Prof. S. Suzuki, Prof. H. NisI and Prof. K. NisniDA who have given the author valuable advices, and Prof. R. Kanehira and Prof. M. Fuztoka who kindly prepared for the author some of the samples used in the present investigation.

The author wishes also to thank Mr. K. Yosrmuka who assisted him in the practical work of the experiments.

The author is indebted to the Imperial Academy for a part of the expense of this investigation.

\section{SUMMARY}

Five separate X-ray investigations of wood are described.

In the first, the Sherrer tube is used. The gitter constants and dimensions of the unit crystal are calculated.

In the second, the causes of the various diffraction patterns of the wood are explained.

In the third, the relation between the strength of woods and LAUE or Powder patterns of diffraction figures are discussed.

In the fourth, a method of determining the inner strain distribution in wooden material without damaging it, is described.

In the fifth, the absorption coefficients of many species of wood are measured and compared with values calculated theoretically. 


\section{BIBLIOGRAPHY}

1 Nigfir, C. Beobachtung über das Verhalten des polarisirten Lichtes gegen pflanzliche Organisation. Sitzungsiberichten der Akademie der Wissenschaften zu München. Bd. 4 (1) 29) -324 (1862) u. Bd. 4 (2) 120-154 (1862).

2 Ningkwa, S. and ONo, S. The Transmission of X-ray through Fibrous, Lamellar and Granular Substances, Proc. Math. Phys. Soc. Tokyo, 7, 131. 1913.

3 Nrankswa, S. Spectrum of X-rays obtained by Means of Lamellar or Fibrous Substances, Proc. Math. Phys. Soc. Tokyo, 7, 296. 1914.

4 Hekznc, R. O., Jaxicki, W. and Polakvt, M. X-ray spectrographic Observations with Cellulose I and II, Z. Physik 3, 196, 343. 1921.

5 II:zoG, R. O. X-ray Spectrographic Investigation of Cellulose, Cellulosechemie 2, 101. 1921.

6 IIfzzo, R. O. The Deformation of Cellulose, Papierfabrik. 21, 388. 1923.

7 Hrss, K., Writzinx, W. and Messmer, L. Cellulose VIII, Liebrg's Ann. 435, 1. 1923.

8 Ramav, C. V. The Scattering of X-ray in Liquids, Nature 111, 185. 129. 1923.

9 Ginel., H. W. X-ray Observations on Cellulose, Z. Physik 25, 118. 1924.

$10 \mathrm{Katz}, \mathrm{J} . \mathrm{R}$. and Mark, H. The Fibre Diagram of Cellulose Hydrate and the Manner of its Reversion, Z. Elektrochem. 31, 105. Changes in the X-ray Powder Pattern of Cellulose due to its Swelling in Concentrated Aqueous Solutions, Z. physik. Chem. 115, 385. 1925.

$11 \mathrm{~K} A \mathrm{r}, \mathrm{J}$. R. and VIrws; , W. The Relation between the X-ray Diffraction Pattern and the Alkali Content during Swelling of Cellulose in Aqueous and Alcoholic-aqueous Sodium Hydiroxide, Z. Elektrochem, 31, 157. 1925.

12 Srinst.f., O. L. X-ray Diffraction Patterns from Plant Fibres, J. Gen. Physiol. 9, 221. 1925 .

13 Herza, R. O. The Nature of the Structure of Cellulose and its Significance in Chemical Transformations, J. Phys. Chem. 30, 457. 1926.

14 Sronster, O. L. Molecular Structure of Plant Fibres Determined by X-rays, J. Gen. Physiol. 9, 677. 1926.

15 Sinst.r., O. L. and D.re, W. H. The Structure of Ramie Cellulose as Derived from X-ray Data, "Fourth Colloid Symposium Monograph" 1926, 174; see also Freumineke, K., Liebig's Ann. 451, 130 (1928). 1926.

16 Hengstranperg, J. and Mark, H. The Form and Size of the Micelles of Cellulose and Rubber, Z, Krist. 69, 271. 1928.

$17 \mathrm{Hrk \%}, \mathrm{R}$. O. Chemistry and Physics of Artificial Silk, Z. angew. Chem. 41, 531 ; J. Textile Inst. 19, 138.1928.

18 Hekzר, R. O. and Jancke, W. The X-ray Diagram of Cellulose, Z. physik. Chem. 139 A, 235.1928.

19 Herz), R. O. and Jancks, W. X-ray Observations on Cellulose IV, Z. Physik 49, 27. 1928.

29 Hegzx, R. O. and JAncke, W. X-ray Observations on Cellulose. Naturwissenschaften $16,618.1928$.

21 Hғss, K. and Trogts, C. Cellulose, Ber. 61B, 1982; Discussion by MEYir, K.H., and MARK, H., Ber. 61 B, 2432. 1928.

22 Mark, H. The Physical Basis of Natcis.'s Micelle Theory, Naturwissenschaften 16, 892. 1928. 
23 Msk , H, and v. Stisch, G. The Orderly Micellar Structure of Rubber, KolloidZ. $46,11.1928$.

24 MEYr., K. II. New Methods in Organic Structure Theory and in the Investigation of Highly Polymerized Compounds, Z. angew. Chem. 41, 935. 1928.

25 Mi:rr, K. H. and MARk, H. The Structure of the Crystalline Components of Cellulose, Ber. 6133, 593. 1928.

26 Sprisitr, O. L. Erroneous Determination of the Cellulose Space Lattice, Naturwissenschaften 16, 263; cf. Potany, M., Ber. 16, 263. 1928.

27 Sronstik, O. L. X-ray Methods in Determining Structure of Cellulose Fibres. Organomolecular Investigations, Ind. Eng. Chen., 20, 1060. 1928.

28 Srokstr, O. L. The Molecular Structure of the Cell Wall Fibres. A Summary of X-ray Investigations, Am. J. Bot. 15, 525. 1928.

29 Sponsler, O. L. and D.r., W. H. The Structure of Mercerized Cellulose I. The Space Lattice of Mercerized Ramie Celluluse as Developed from X-ray Data, J. Am. Chem. Soc. 50. 1940. 1928.

$30 T_{\text {Rncrs, }}$ C. Relation Between Swelling, Salt Formation and Microstructure in the Cellulose Fibre, Zellstoff u. Papier 8, 798; Papierfabrik. 27, 55 (1929). 1928.

31 Anderss, K. R. The Intensities of X-ray Diagrams of Native Cellulose, $Z$. physik. Chem. 2B, 380. The X-ray Diagram of Mercerized Cellulose, Z. physik. Chem. 4B, 190. 1929.

32 Brill, R, and Plitzsk, H. A New Method for X-ray Determination of Particle Size, Z. tech. Physik 10, 663. 1929.

33 Herzor, R. O. and JAxcks, W. Deformation of Fibres, Z. Physik 52, 755. 1929.

34 Hess, $K$. and Tenctis, C. X-ray Investigations on Cellulose Derivatives 111. Reversible and Irreversible Lattice Changes of Cellulose Triacetate, Z. physik. Chem, 5B, 161. 1929.

35 Mark, H. The Determination of Particle Size by the Use of X-rays, Trans. Fasamay Soc. 25, 387. 1929.

36 MaRk, HI. The Structure of Cellulose and its Technical Importance, MEldandsas Textilber. 10, 695. 1929.

37 M^кк, H. and Mern, K. H. Structure of the Crystalline Part of Cellulose II, Z. physik, Chem. $2 \mathrm{~B}, 115$.

38 Mark, H. and v. Sisrer, G. Short Exposure Times for X-ray Photographs, Naturwissenschaften 17, 803. 1929.

39 Mrrfr, K. H. The Chemistry of Micelles and their Application to l3iochemical and Biological Problems, Biochem. Z. 208, 1. 1929.

40 Tronis, C. and Hess, K. X-ray Investigations on Cellulose Derivatives II. The Space Jattice of Methyl Cellulose, Z. physik. Chem. 4B, 321. 1929.

41 Trnor, C. and H:ss, K. X-ray Investigations on Cellulose Derivatives IV. The Fibre Diagram of Copper Alkali Cellulose Z. Physik. Chem, 6 B, 1. 1929.

42 C.ARJ, G. L. The Presennt Status and Future Possibilities of X-ray Research on Textiles, Proc. Am. Assocn. Text. Chem. Colorists 1930, 48; Am. Dyestuff Reptr. 19, 60. 1930.

$43 \mathrm{Cl}, \wedge k \mathrm{~K}, \mathrm{G}$. L. and Cinkign, , K. L. The Long Spacings of Rubber and Cellulose, Radiology 15, 117. 1930. 
44 Eckline, K. and $\mathrm{K}_{\mathrm{ka} \text { a }} \mathrm{K}, \mathrm{O}$. X-ray Histologicel Stuclies I. Determination of the Texture of Individual Ramie Fibres by the X-ray Micro Method, Z. physik. Chem. $10 \mathrm{~B}, 868.1930$.

45 Hiss, K. Swelling and Solution Processes of Cellulose and its Derivatives, Papierfarbrik. 28, 169; Zellstofl Papier 10, 23. 1930.

46 HIss, K. and Tkuab: C. Higher Orientations of Cellulose Materials, Naturwissenschaften 18, 437. 1930.

47 Ifess, K. and Trucus, C. The X-ray Fibre Diagram of Trimethylcellulose and of Triacetylcellulose II, Z. physik. Chem. $9 \mathrm{~B}, 160.1930$.

48 Katz, J. R. The Problem of Swelling of Cellulose and its Derivatives, Cellulosechem. 11, 17. 1930.

49 Makк, HI. X-rays in Fibre Research, Kunstseide 12, 214; Jiیtian's Rayon Rev. 2, 196. 1930.

59 Mark, H. and v. Sisicn, G. X-ray Studies on Methylcellulose, Z. physik. Chem. 9 B, 157. 1930 .

51 Spukilik, O. J. New Jata on Cellulose Space Iettice, Nature 125, 633. 1930.

52 Stelid, M. The Structure of Celiulose, Nitrocellulose 1, 32. 1930.

53 BRAGG, W. 11. Cellulose in the Light of X-rays, Cellulose 1, 80, 110; Nature 125, 315. 1925 .

54 Astutik , W. T. The Molecular Structure of Natural Fibres, Summary of Lecture Delivered at Univ. Manchester, July 10, 1931. 1931.

55 C.x, F. G. An X.ray Exmamination of Arabinose, Xylose and Rhamnose, $\boldsymbol{j}$. Chem. Soc. 1931, 2313. 1931.

56 Hes;, $\mathrm{K}$. and Trirti, C. X-ray studies of Cellulose Derivatives VIII. The Alkali Celluloses, Z. physik. Chem. $11 \mathrm{~B}, 381.1931$.

57 Hes.i, K. and TRas.;, C. The Fibre Periods of Cellulose Derivatives Z. Physik. Chem. B bexstFin-Festband, 385. 1931.

58 Hess, K., Trugus, C., Akim, L. and Sakgrada, I. Morphology and Chemism in Cellulose Fibres, Ber. 64B, 408. 1931.

59 HinerkT, H. and Barsha, J. Structure of the Cellulose Synthesized by the Action of Acetobackter xylinus on Glucuse, Can. J. Research 5, 580. 1931.

60 KLAGfis, F. Cellulose XLII. Formation from Cellulose Fibres of a Crystalline Carbohydrate Soluble in Water and Giving the X-ray Diagram of Hydro. cellulose, Ber. 64 §, 1193. 1931.

61 Prexuwski, S. O uporzadkowaniu krystalitow celulozy $w$ drzewie. 1931.

62 Scinamis, W. and Sintreт, C. The X-ray Fibre Diagram as a Quantitative Measuring Stick for Changes of Structural Units of Cellulose Fibres through Chemical Processes I. The Quantitative Relation between the Intensity of the Equatorial Interference of Known Combinations of Fibres of Native and Mercerized Cellulose, Z. physik. Chem. 13 B. 462. 1931.

63 Tronus, C. and Hris; K. X-ray Investigations of Cellulose Derivatives IX. The X-ray Diagram of Trinitrocellulose-a Contribution to the Knowledge of Stablization Changes, Z. physik. Chem. 12B, 268. 1931.

64 Trous, C. and Hrss, K. Additive Compounds of Cellulose with Hydrazine, Ethylenediamine and Tetramethylenediamine, Z. physk. Chem. 14B, 387. 1931.

65 Yoshin, U. and Matsonur, N. X-ray Diffraction Pattern of Native Cellulose, Mem. Coll. Sci. Kyoto Imp. Univ. 14 A, 115. 1931. 
66 Friedenrara, K. The Relationt of Cellulose to Lignnin in Wood, Papier-Fabr. 30, Tech-Wiss. Teil 189; J. Chem, Education 9, 1171. 1932.

67 Hrss, K. Old and New Viewpoints as to the Structure of Cellulose and their Experimental Buses, Uspehhi Khim. (Trogress Chem. U.S.S.R.) 1, 669. 1932.

68 Ohara, K. and Matsuciaca, Y. The Submicroscopic Structure of Silk II. X-ray Investigation of Dichroism of Silk, Bull. Inst. Phys. Chem. Research (Tokyo) 11, 769. 1932.

69 Yoshma, U. and Tafia, B. Net Density of Ramie-Cellulose, Mem. Coil. Sci. Kyoto Imp. Univ. 15A, 1. 1932.

70 Astruky, W. T. The X-ray Interpretation of Fibre Structure, J. Soc. Dyers and Colourists, June 1933, p. 169.

71 Astrery, W. T. The X-ray Interpretation of Fibre Structure, Sci. Progress No. $110,210.1933$.

72 Atsuk: K, and Ishwnsi, M. The Structure of Cellulose Gel V. The Structure of Natural Cellulose Fibre Revealed by X-ray Analysis, J. Soc. Chem. Ind. Japan 36, Suppl. binding, 517. 1933.

73 Arsukr, K. and Ishrwar.4, M. The Structure of Viscose Silk and Cellophane Analyzed by X-ray, J. Soc. Chem. Ind. Japan 36, Suppl. binding 540. 1933.

74 Champrtik, G. Addition Compounds of Cellulose, Ann. chim. 20, 5. 1933.

75 Chamieter, G. The Action of Orthophosphoric Acid on Ordinary Cellulose, Compt. rend. 196. 930. 1933.

76 Hess, K. and Trogus, C. Remarks on the Work of W. Schramek; "The X-ray Fibre Diagram as a Quantatitive Measure for the Change of Building Units of Cellulose Fibers by Chemical Processes," Z. physik, Chem. 21B, 349. 1933.

77 JENKINS, W. J. Function of Plasticizers in Cellulose Derivatives Ind. Chem. 9, 204. 1933.

78 Ogtri, S. Chemical Investigation of Bamboo X. X-ray Study of Bamboo Cellulose, Cellulose Ind. (Tokyo) 9, 59 ; Abstr. in Eng. 1. 1933.

79 Saxples, J. P. and Castron, F. K. Unit Cell of Cellulose in Cotton Stalks and Cusps, lind. Fing. Cheñ. 25, 1371. 1933.

89 Sclimame, W., Nicyans, II. and Schumfr, C. The X-ray Fibre Diagram as a Quantitative Measure of Changes in the Micelles of Cellulose by Chemical Processes II. The Application of Mixed Preparations to the Measurement of Partial Change in the Effect of Aqueous Sodium Hydroxide on Cellulose, Z. physik. Chem. 20b, 269. 1933.

81 Sran, W. A and Crakk, G. L. X-ray Method for Quantative Comparison of Crystallite Orientation in Cellulose Fibres, Ind. Eng. Chem., Anal. Ed. 5, 296. 1933.

82 K LxMrn, N. H. and Hry, A. N. J. The Hydration Film of Cellulose in Cell Walls, Proc. Acad Sci. Amsterdam 37, 92. 1934.

83 Leuck, G. J. and MAk, H. An X-ray Examination of the Acetates of Glucose, Cellobiose and Cellotriose, J. Am. Chem. Soc. 56, 1959. 1934.

84 Msturfo, M. Structure of Cellulose and its Derivatives, Compt, rend, 198, 1434. 1934.

85 Matsumuto, N. The Distance between the Micelles in Viscose Rayon, J. Sac. Chem. Ind. Japan 37, Suppl. binding 356. 1934.

86 Retter, G. J. and Sriliwill, C. W. Rate of Formation of the Crystalline Structure of Wood Fibres, Paper Trade J. 98, No. 22, 37. 1934. 
87 Sakurafa, I. and Himino, K. Ring Fibre Structure and Orientation of Micelles in Films as Shown by X-rays, Sci. Jap Inst. Phys. Chem. Research (Tokyo) 24. 193. 1934.

88 Sison, W. A. X-ray Analysis of Textile Fibres II. Experimental Methods ; Singlefibre Studies; Adsorption Effects; Fibre Decomposition; Oxidized Cellulose and Fibre Structure, Textile Research 4. 286. 1934.

89 Tumonsri, T. Cellulose LII. Method of Reaction of Cellulose 4. The Mechanism. of the Denitration of Nitrocellulose, Z. Elektrochem. 40, 207. 1934.

90 Fakr, W. K. and Sssston, W. A. X-ray Diffraction Patterns of Cellulose Particles and Interpretations of Cellulose Diffraction Data, Contrib. Bryce. Thompson Inst. $6,31 \ldots 1934$.

91 Yosind, U. and PARK, C. Further Investigation on the X-ray Diffraction Pattern of Native Cellulose. Mem. Coll. Sci. Kyoto Imp. Univ. 17 A, 6. 1934.

92 A stituents from vegetable fibres. Nature, 136, 391. 1935.

93 Schramek, W. and Gikg, II. X-ray investigation of the reversibility of the spacelattice transformation with sodium hydroxide cellulose. Kolloid-Beiheft, 42, 302. 1935.

94 Sisson, W. A. X-ray studies of crystallite orientation in cellulose fibers. J. Ind. Eng. Chem, 27, 51. 1935.

95 Sisson, W. A. X-ray analysis of textile fibres. III, Structure of the cellulose crystallite as interpreted from X-ray diffraction data, Textile Research, 5, 119. 1935.

93 Tiromas, E. N. M. and Hritr, I. X-Strahlen Beugungsdiagramm von Sisal, Kokos und Eiche. Cellulosechem., 17, 27, 1935.

97 Yusmida, L. and Matschuto, N. On the Micell Size of Cellulose. J. Soc. Chem. Ind. Japan. 38, 460. 1935.

98 Hess, K. and Gunotrmane, J. Structure of the Water Envelope in micelles of organic Colloids. Zeits. f. Phys. Chem. 34, Abt. B. 1-2. 1936.

99 Kus, T. Parallel Orientation of Christallite in Articificial Silk. The World of Artificial Silk. Japan. No. 37, 10. 1936.

100 Ktire, S. and Kcri, T. Relation between the internal Structure of Cellulose and its mechanical Properties. J. Soc. Chem. Ind. Japan. 39, 929. 1936.

101 Marsumiti, N. X-ray Studics of Water Satisfied Cellulose. J. Soc. Chem. Ind. Japan. 39, 479, 1936.

102 TAtaks, S. and Mos, Z. X-ray Studies of wood Texture. The World of Artificial Silk. Japan. No. 39, 1, 1937. 


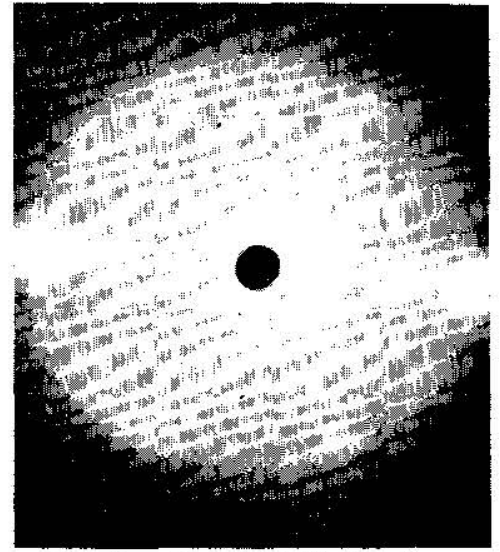

Fig. 1. Albizzia julibrisin Boiv.

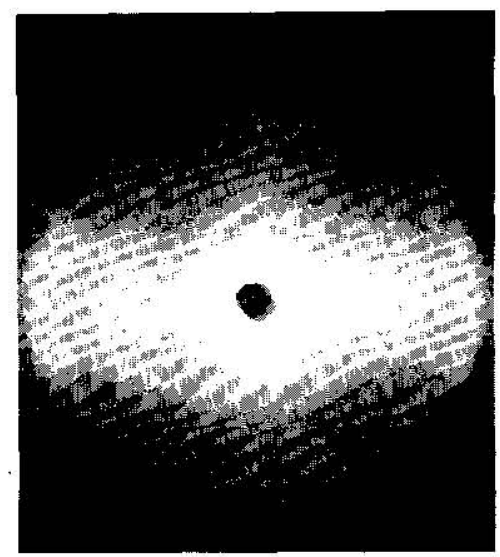

Fig. 3. Pinus Thunbergii PARL.

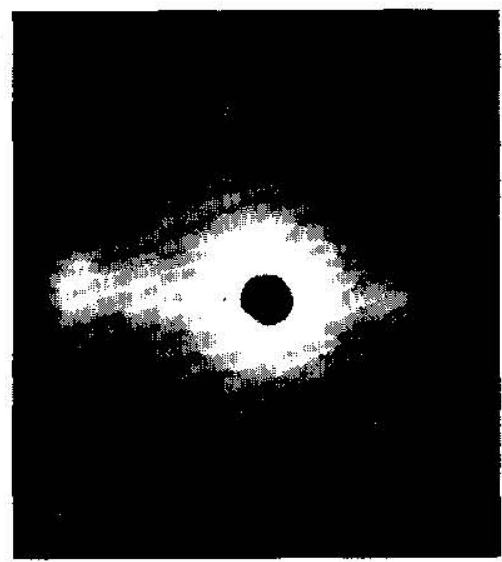

Fig. 5. Thujopsis dolabrata S. et Z. (Radial section).

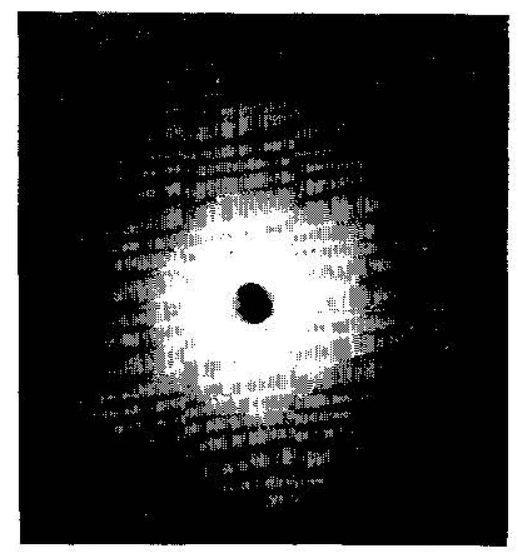

Fig. 2. Chamaecyparis obtusa S. et Z.

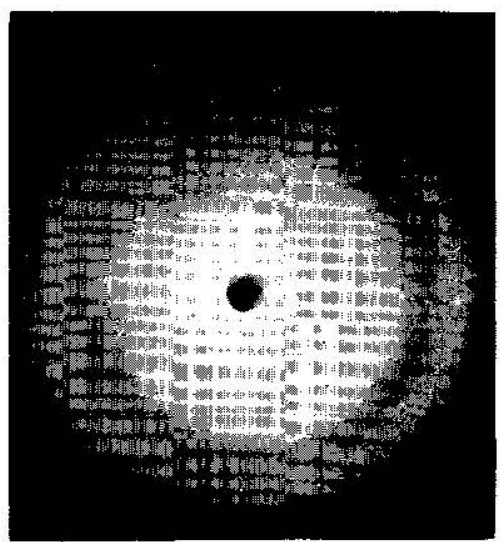

Fig. 4. Quercus crispula $\mathrm{BL}$.

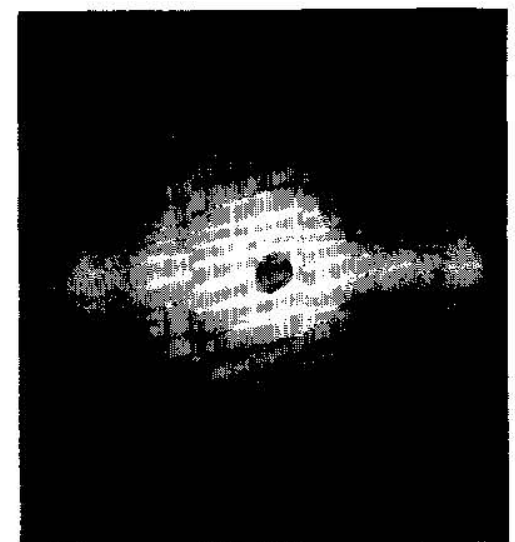

Fig. 6. Thujopsis dolabrata S. et Z. (Spring wood). 


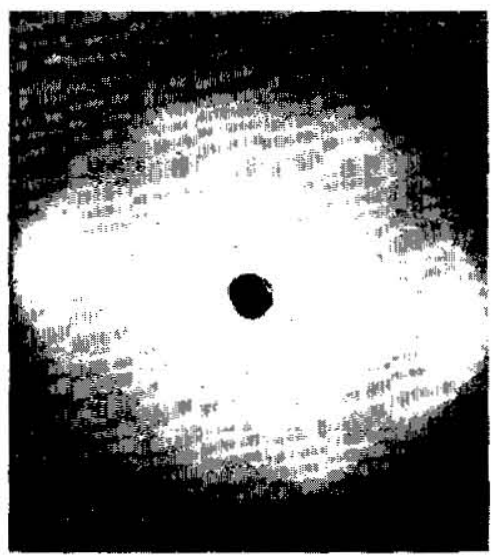

Fig. 7. Thujppsis delabrata S, et Z. (Tangential section).

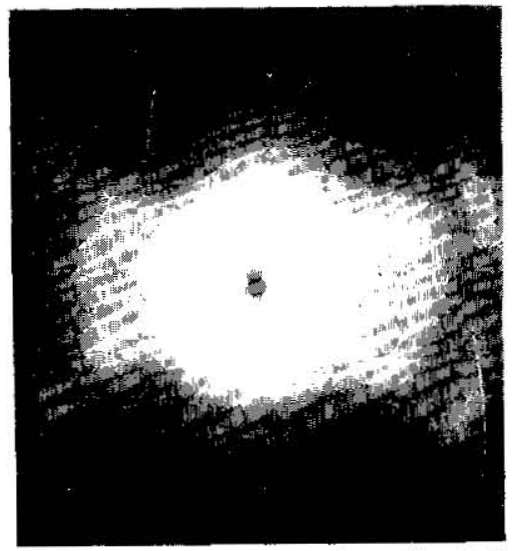

Fig. 9. Chamaecyparis obtusa S. et Z.

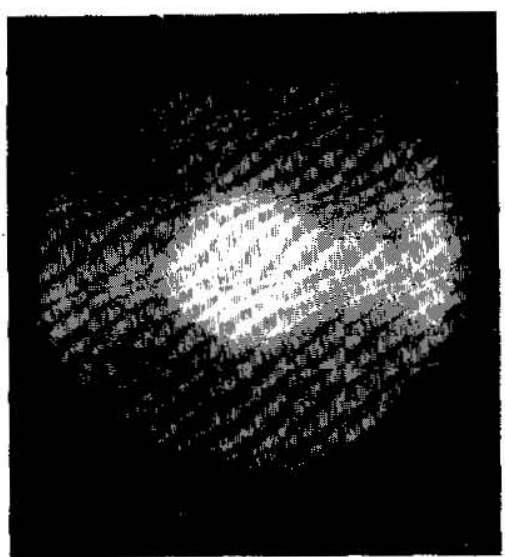

Fig. 11. Pinus Thunbergii Part. (Spring woodi.

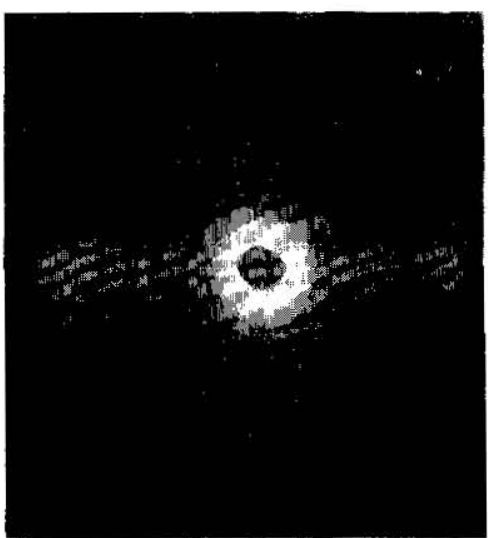

Fig. 8. Thujcpsis dolabrata S. et $Z$. (Summer wood.

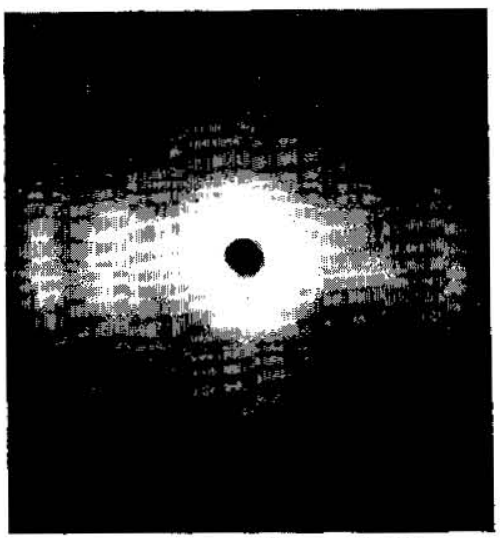

Fig. 10. Pinus Thunbergii $\mathrm{P}_{\text {ARL. }}$ (Summer wood).

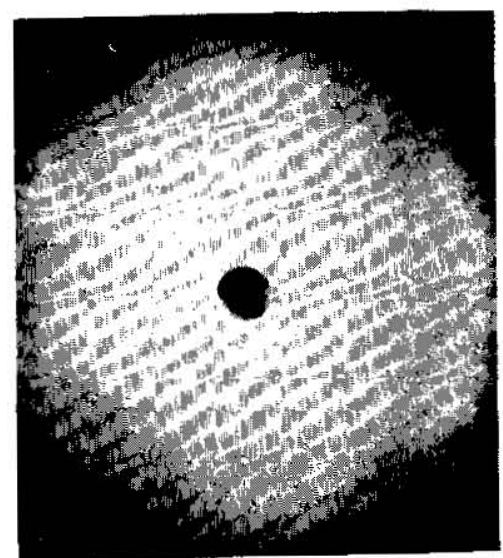

Fig. 12. Pinus densiffora $\mathrm{S}$. et $\mathrm{Z}$. 


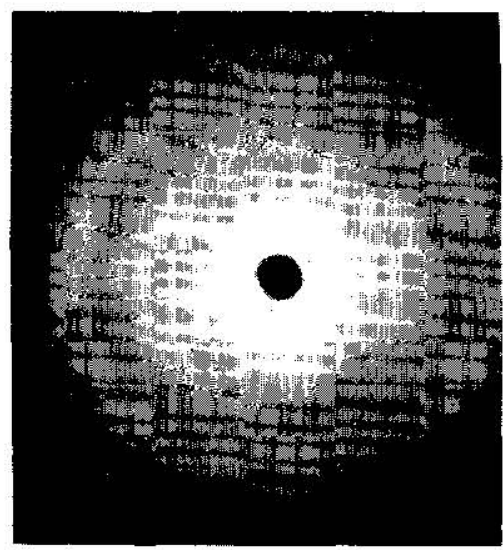

Fig. 13. Podocarpus Nogi PILGER

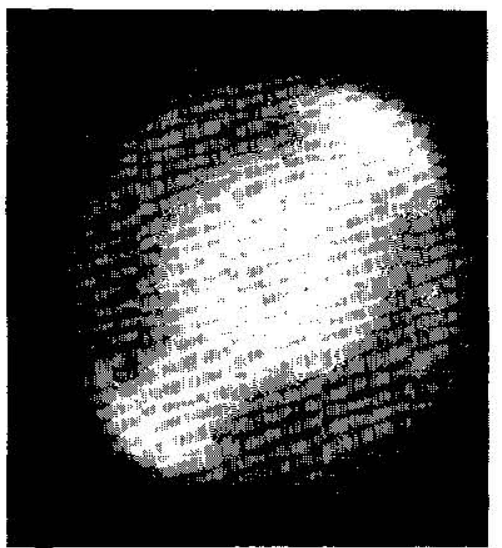

Fig. 15. Populus Maximowiczii A. HFNRY

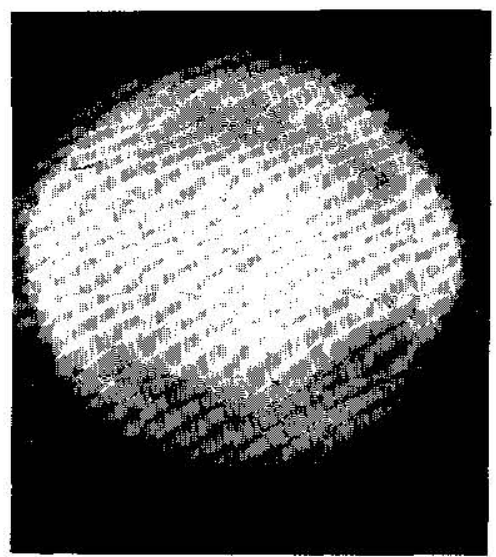

Fig. 17. Acer palmatum Tifins.

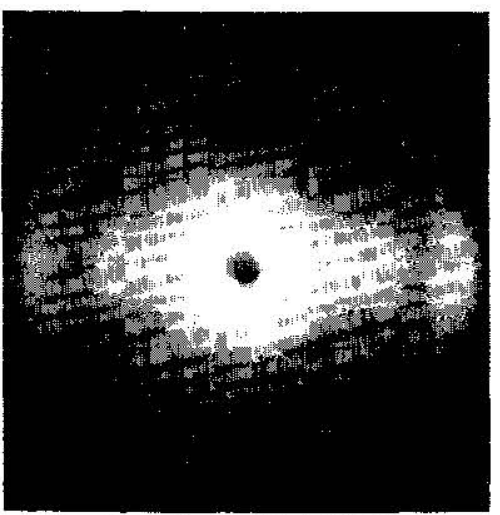

Fig. 14. Tsuga Siebcldii CAnR

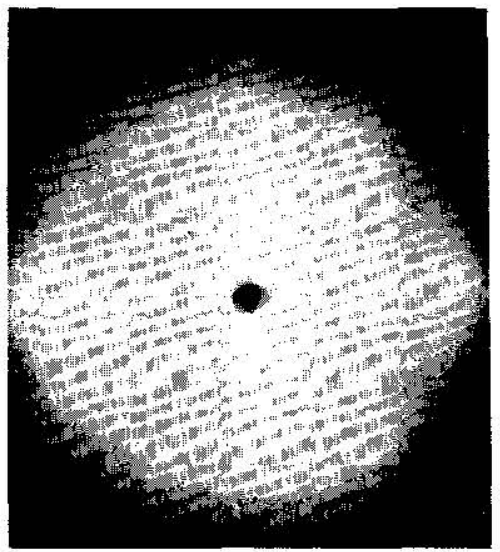

Fig. 16. Kalopanax pictum NıKA

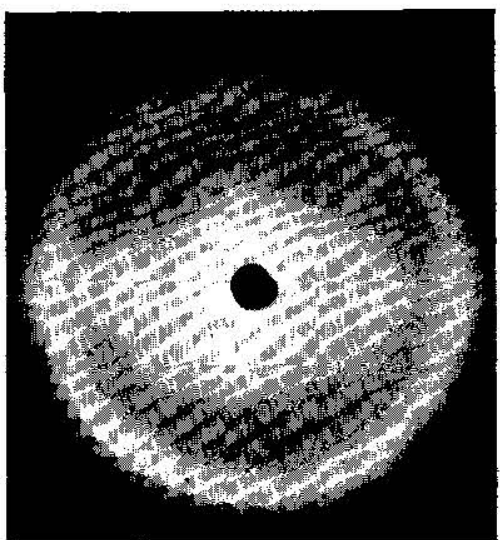

Fig. 18. Fagara ailanthoides Exics. 


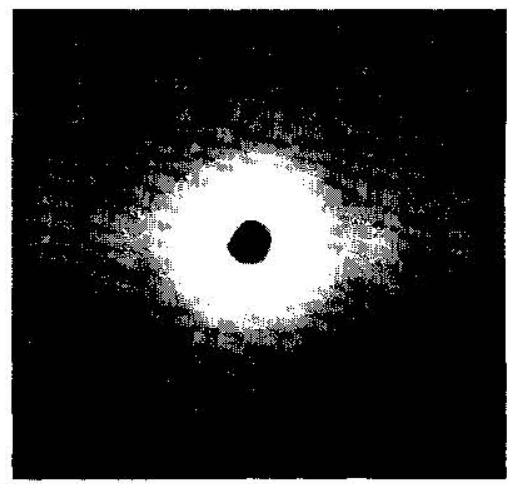

Fig. 19. Zelkowa serrata Makno

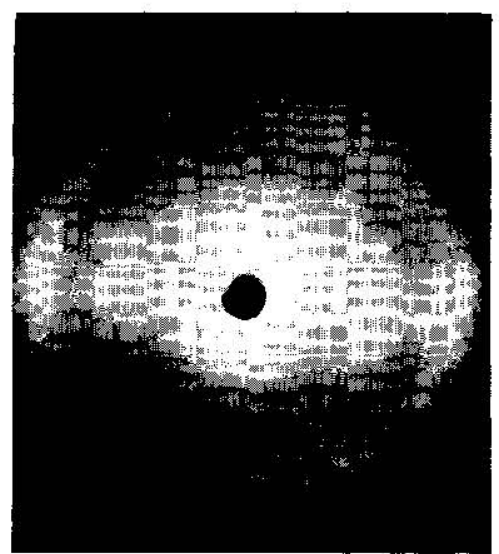

Fig. 21. Castanea crenata S. et $Z$. (Summer wood).

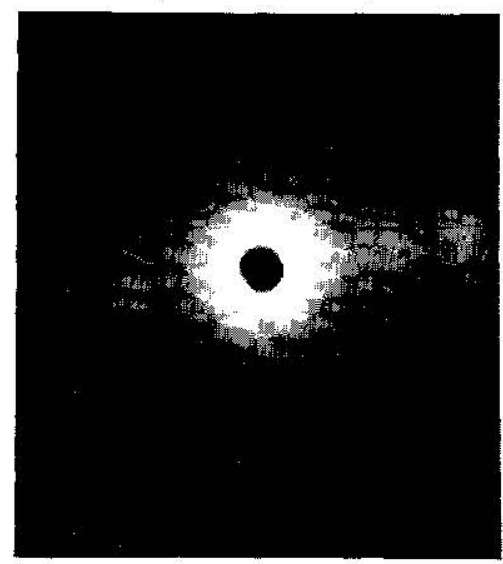

Fig. 23. Ilex rotunda ThlNB.

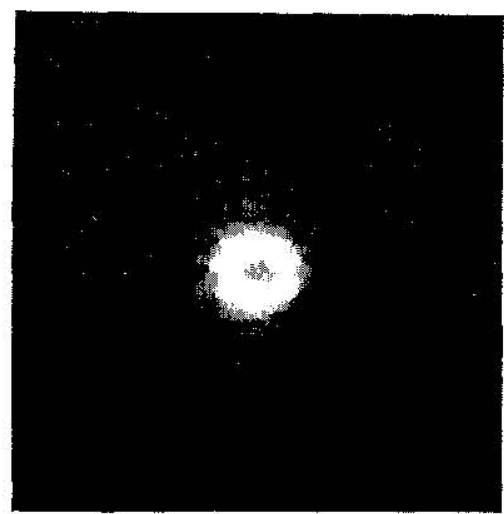

Fig. 20. Diospyros peregrina GürkF.

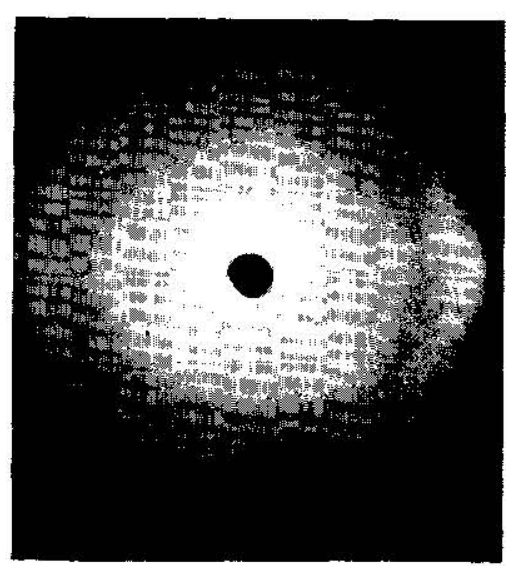

Fig. 22. Castanea crenata $\mathrm{S}$. et $\mathrm{Z}$. (Spring wood).

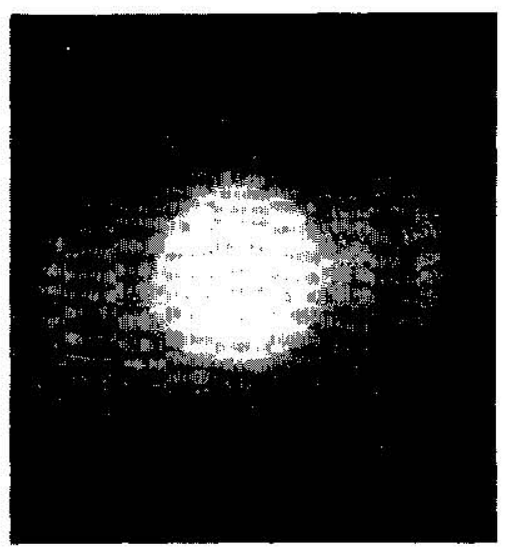

Fig. 24. Quzrcus crispula BL. 


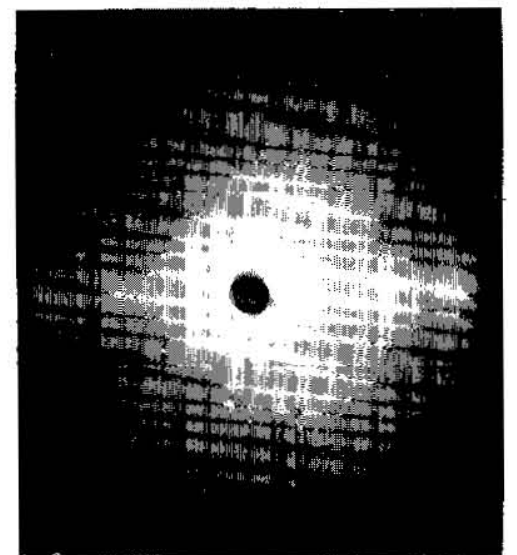

Fig. 25. Quercus crispula $\mathrm{BL}$. (Summer wood).

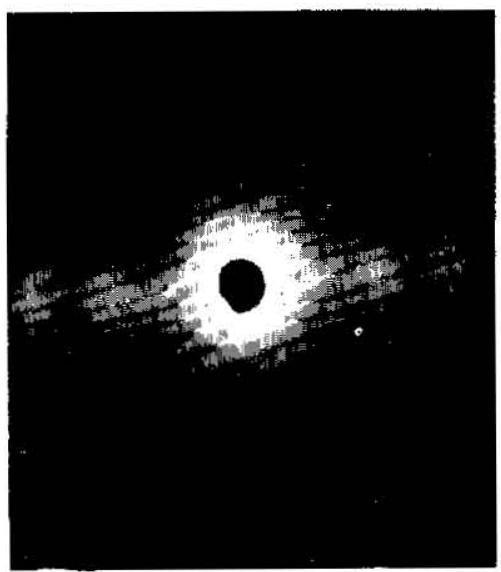

Fig. 27. Fraxinus japonica $\mathrm{BL}$. (Summer wood).

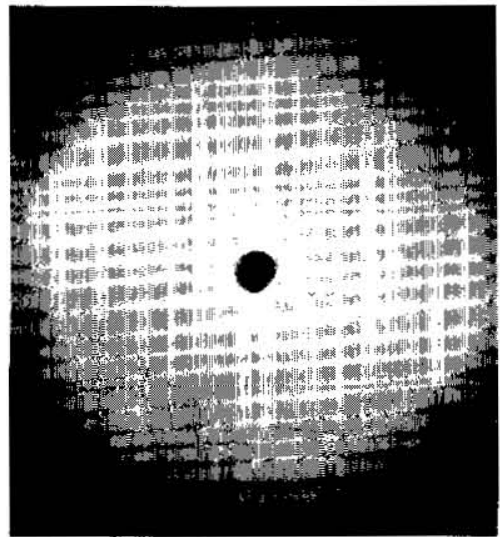

Fig. 29. Myrica rubra S. et Z.

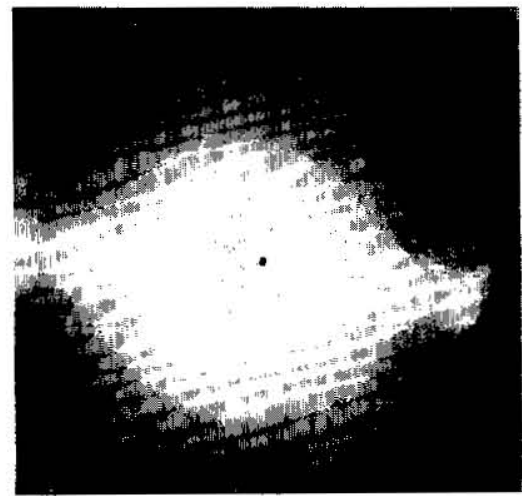

Fig. 26. Quercus crispula Br. (Spring wood).

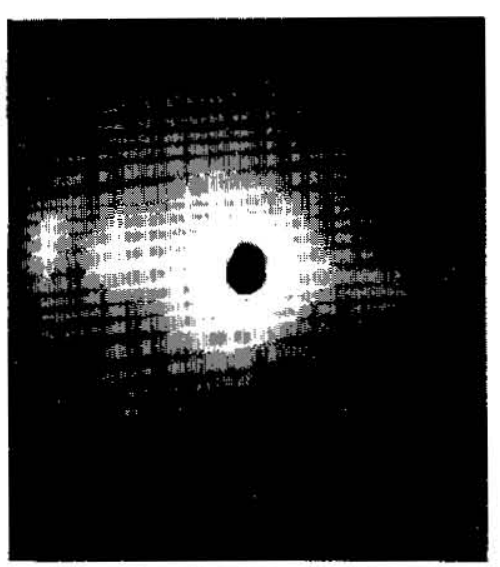

Fig. 28. Fraxinus japonica B.. (Spring wood).

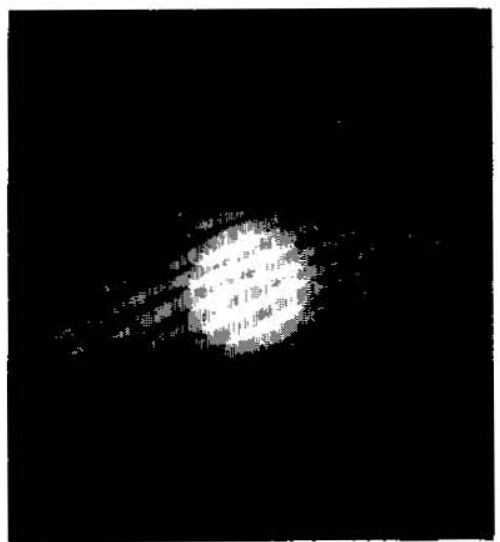

Fig. 30. Fraxinus mandschurica Rcpr. 


\section{ERRATA}

Journal of Agriculture, Kyushu Imperial University,

Vol. 5, No. 5. May 1. 1937.

Page 237, line 10 from bottom: For refletion read refraction.

Page 238, line 6: For off read of.

Page 244, line 9 from bottom: For Fe read $\mathrm{FeK}_{\alpha}$.

Page 249, line 1:

$$
\begin{aligned}
& \text { For } \mathrm{r}=\frac{2 \mathrm{~S} \omega v^{\prime} \overline{\omega^{2} f-\omega^{2} p}}{2 \omega^{2} p-\sin ^{3} \zeta}
\end{aligned}
$$

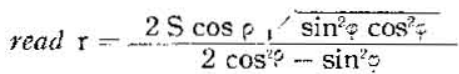

Page 250, line 5: For atom read beam

Page 251, formula (2), For $\left(\frac{\mu}{p}\right) C_{\text {lign. read }}\left(\frac{\mu}{\rho}\right)_{\text {lign. }} C_{\text {lign }}$ 